\title{
Common Agency and the Public Corporation
}

Paul Rose

63 Vand. L. Rev. 1355 (2010)

Under the standard agency theory applied to corporate governance, active monitoring of manager-agents by empowered shareholder-principals will reduce agency costs created by management shirking and expropriation of private benefits. But while shareholder power may result in reduced managerial expropriation, an analysis of how that power is often exercised in public corporation governance reveals that it can also produce significant costs: influential shareholders may extract private benefits from the corporation, incur and impose lobbying expenses, and pressure corporations to adopt inapt corporate governance structures. These costs strain the simple principal-agent model on which shareholder empowerment is based. This Article offers an alternative model-a common agency theory for public corporations. A common agency is created when multiple principals influence a single agent; in the case of a corporation, common agency describes a shareholder/management relationship in which multiple shareholders with competing preferences exert influence on corporate management. The common agency theory set out in this Article provides several important contributions to the literature on corporate governance and shareholder empowerment. First, the theory provides a more complete explanation of the motivations for and outcomes of shareholder activism, including the activities of governmental owners, large institutional investors, and "social" investors. Second, the theory helps to delineate more clearly the costs and benefits of increasing shareholder power. Finally, building on these findings, the theory suggests possible regulatory changes to ensure that the benefits of shareholder activism outweigh its costs. 


\title{
Common Agency and the Public Corporation
}

\author{
Paul Rose*
}

INTRODUCTION

I. COMMON AGENCY THEORY AND ITS APPLICATION TO

PUBLIC CORPORATIONS .................................................. 1361

A. Evidence of Common Agency in Public

Corporations

1. Shareholder Influence in Public

Corporations

2. Heterogeneity of Interests Among

Public Company Shareholders

a. Heterogeneity in Social

Preferences

b. Heterogeneity in Corporate

Governance Preferences

c. Heterogeneity in Investor

Expectations.

II. GOVERNANCE IMPLICATIONS OF COMMON AGENCY

A. Shareholder Activism and Corporate

Performance: A Review of the Literature.

B. Private Benefits from Shareholder Activism

C. 1388

1. Lobbying Costs 1388

2. Efficiency Costs 1389

3. Cross-Shareholder Monitoring and Shareholder Bonding Costs 1393

Assistant Professor of Law, Ohio State University - Moritz College of Law. Thanks to Steve Davidoff, Garry Jenkins, Dale Oesterle and Roberta Romano for many helpful comments and suggestions, and thanks also to Jennifer Arlen, Sam Buell, Jill Fisch, Todd Henderson, Don Langevoort, Eric Talley, and participants at the Conference on New Research in Regulation of Corporations, Managers, and Financial Markets (Washington University School of Law), the Ohio Legal Scholarship Workshop, and the University of Cincinnati College of Law Faculty Workshop for comments on an earlier version of this Article. All errors are mine. 
III. REGULATORY IMPLICATIONS OF COMMON AGENCY:

PRELIMINARY CONSIDERATIONS ...................................... 1394

A. Regulating Agency Costs Through

Fiduciary Duties ............................................... 1396

1. Fiduciary Duties Owed by

Fund Managers to Investors ..................... 1397

2. Shareholder Fiduciary Duties to the

Corporation and Other Shareholders ........ 1401

3. Duties Owed by Managers to

Shareholders............................................... 1405

B. Regulation by Disclosure ...................................... 1406

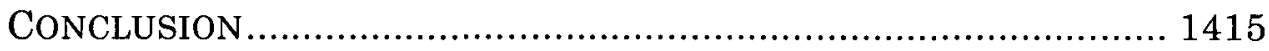

\section{INTRODUCTION}

Despite some durable economic ${ }^{1}$ and regulatory ${ }^{2}$ limitations on shareholder activism, two general trends have supported increased shareholder power and influence within public companies in recent years. First, U.S. markets have become increasingly institutionalized, ${ }^{3}$ and institutional ownership of public companies has tended to reduce some of the collective action problems that have impeded shareholder activism in the past. Second, courts and federal regulators have increasingly promoted shareholder influence through various decisions ${ }^{4}$ and regulatory actions, including Securities and Exchange Commission ("SEC") efforts to liberalize communications with respect

1. Most investors, including institutional investors, remain "reluctant activists." Robert C. Pozen, Institutional Investors: The Reluctant Activists, 72 HARV. BUS. REV. 140 (1994). This is partially due to the costs associated with activism such as the printing and mailing costs associated with proxy nominations, although these costs have diminished with the passage of the SEC's new "e-proxy" rules. The distraction of management and investment personnel who participate in the activism remains a significant cost.

2. Some regulatory restrictions continue to impede certain kinds of shareholder activism, although the intent of some of these regulations, such as Regulation 13D of the Securities Exchange Act of 1934, is to regulate the market for corporate control rather than to reduce shareholder activism. 17 C.F.R. $\$ 243.101$ (b) (2010). Regulation FD also reduces some kinds of shareholder influence, particularly affecting negotiations between corporations and institutional investors. See Joseph W. Yockey, On the Role and Regulation of Private Negotiations in Governance, 61 S.C. L. REV. 171 (2009).

3. Donald C. Langevoort, The SEC, Retail Investors, and the Institutionalization of the Securities Markets, 95 VA. L. REV. 1025 (2009).

4. See, e.g., Med. Comm. for Human Rights v. SEC, 432 F.2d 659, 662-63 (D.C. Cir. 1970); Lovenheim v. Iroquois Brands, Ltd., 618 F. Supp. 554 (D.D.C. 1985); Adoption of Amendments to Proxy Rules, Exchange Act Release No. 9784, 1972 SEC Lexis 155 (Sept. 22, 1972). 
to proxy voting, ${ }^{5}$ the SEC's recent "e-proxy" rules, ${ }^{6}$ the imposition of fiduciary duties on certain fund managers (and the resulting importance of corporate governance ratings firms and proxy advisory firms that help funds meet their fiduciary duties), ${ }^{7}$ and the elimination of broker discretionary voting. ${ }^{8}$

5. See Regulation of Communications Among Shareholders, Exchange Act Release No. 3,431,326, 57 Fed. Reg. 48,276 (Oct. 22, 1992) (to be codified at 17 C.F.R. pts. 240, 249). As Jill Fisch has argued, the SEC's efforts have had a substantial effect on shareholder power within the public corporation:

[T] rights in an increasingly large and impersonal voting system. Instead, the rules change the voting process, both by determining issues upon which shareholder democracy is appropriate and by structuring the way in which such democracy can be exercised.

Jill E. Fisch, From Legitimacy to Logic: Reconstructing Proxy Regulation, 46 VAND. L. REV. 1129, 1170 (1993).

6. The SEC's recent "e-proxy" rules have also reduced collective action frictions by making it cheaper and easier for shareholders to communicate with one another. See Jeffrey Gordon, Proxy Contests in an Era of Increasing Shareholder Power: Forget Issuer Proxy Access and Focus on E-Proxy, 61 VAND. L. REV. 475 (2008).

7. 29 C.F.R. $\$ 2509.94-2$ (2008) (fiduciary duties applied to pension funds by the Department of Labor); Proxy Voting by Investment Advisers, 68 Fed. Reg. 6585 (Feb. 7, 2003) (to be codified at 17 C.F.R. pt. 275) (adopting Investment Advisers Act Rule 206(4)-6, 17 C.F.R. $\S$ 275.206(4)-6 (2003)); Disclosure of Proxy Voting Policies and Proxy Voting Records by Registered Management Investment Companies, Securities Act Release No. 8188, 68 Fed. Reg. 6564 (Feb. 7, 2003) (adopting Investment Company Act Rule 30b1-4, 17 C.F.R. $\S 270.30 b 1-4$ (2008), and related amendments to the applicable Investment Company Act forms). Considering that the portfolios of many funds may contain tens and even hundreds of portfolio companies, the costs of reviewing the director elections and management and shareholder proposals on each proxy are enormous. Responding to a market need to deal with this heavy workload, professional proxy advisory firms now assist, and in some cases completely manage, the review and voting of portfolio company proxies. See Paul Rose, The Corporate Governance Industry, 33 J. CoRP. L. 120 (2007).

8. Prior Rule 452 allowed brokers discretion to vote shares of a beneficial owner with respect to "routine" matters unless otherwise instructed by the beneficial owner. Director elections in uncontested elections were treated as routine under the rule. Under the revision, broker discretionary voting is eliminated regardless of whether the election is contested or uncontested. Self Regulatory Organizations, Exchange Act Release No. 34-60215, 96 SEC Docket 654 (July 1, 2009). As other commentators have argued, because of the importance of each vote under such rules, "the elimination of Rule 452 adds significant fuel to 'withhold authority" campaigns initiated by activist hedge funds and other dissident stockholders to advance agendas not necessarily in the best interests of all stockholders." Broc Romanek, SEC Approves Elimination of NYSE Rule 452, DEALLAWYERS.COM BLOG (July 7, 2009), available at http://www.deallawyers.com/blog/archives/001078.html (citing Cliff Neimeth of Greenberg Traurig). SEC Commissioner Troy Parades also expressed concern with the rule change:

Eliminating the discretionary broker vote may cut off an avenue by which the overall preference of retail shareholders can be communicated, thus quieting their voice. In this event, the voice of institutional investors will carry additional weight; yet the interests of institutional investors are not necessarily compatible with the interests of retail shareholders.

Troy Parades, Comm'r, SEC, Statement at Open Meeting to Propose Amendments Regarding Facilitating Shareholder Director Nominations, March 20, 2009, http:/www.sec.gov/news/speech /2009/spch052009tap.htm. Ironically, a problem sought to be rectified by the rule change- the 
The recently enacted Dodd-Frank Wall Street Reform and Consumer Protection Act ${ }^{9}$ (the "Dodd-Frank Act") also enhances shareholder power. Among the most important regulations is the SEC's latest attempt at crafting "proxy access" rules. Under the new rules, shareholders meeting certain ownership criteria would be entitled to include the greater of one nominee or twenty-five percent of the number of board seats that are up for election on the company's proxy. ${ }^{10}$ The Dodd-Frank Act also imposes, among other corporate governance changes, a mandatory "say-on-pay" requirement, ${ }^{11}$ a comply-or-explain provision on the separation of the CEO and board chairman position, ${ }^{12}$ and a clawback provision that would, in the event of a restatement, require an issuer to recover "excess," "erroneously issued" incentive-based compensation from any current or former executive officer of the issuer. ${ }^{13}$

Seemingly spurred on by regulatory competition from the SEC, ${ }^{14}$ Delaware has also responded to the changing landscape of increasing shareholder power. New Delaware General Corporate Law ("DGCL") Section 112 allows the adoption of binding bylaw provisions that, like proposed Exchange Act Rule 14a-11, would permit insurgent access to a company's proxy materials. ${ }^{15}$ New DGCL Section 113

possible lack of an economic interest in the firm by the broker possessing voting power-would reappear as institutional investors follow the advice of proxy advisory firms that have no economic interest in the firm yet determine voting policy for a large percentage of the shareholder vote.

9. Dodd-Frank Wall Street Reform and Consumer Protection Act, Pub. L. 111-203 (2010).

10. All public companies with a market float of $\$ 75$ million or more are immediately subject to the new rules. The rules require that a shareholder must continuously own at least three percent of the total voting power of a company's securities for three years as of the date that the shareholder notifies the company of its proposed nomination. Significantly, the proposed rule also enhances shareholder influence by supporting the formation of groups of shareholders in order to meet the ownership requirements. The SEC attempts to deal with potential conflicts of interest in the nomination process by requiring that any shareholder nominee satisfy the independence standards of the national securities exchange on which the company's securities are listed, and that the company and the nominating shareholder not have any direct or indirect agreement with respect to the shareholder's nomination. The nominating shareholder and the director candidate will also be subject to additional disclosure obligations, including the amount and percentage of securities owned by the nominating shareholder, the length of time of the nominating shareholder's ownership, and information about the nominating shareholder and nominees similar to that required to be provided in a proxy contest. The nominating shareholder must also certify that it is not seeking to change control of the company or to obtain more than minority representation on the board of directors. See Securities Act of 1933 Release No. 33-9136 (Aug. 25, 2010).
11 Dodd-Frank Act $\S 951$.
12 Id. $\$ 972$.
13. Id. $\$ 954$.
14. Mark J. Roe, Delaware's Competition, 117 HARV. L. REV. 588 (2003).
15. See DEL. CODE ANN. tit. 8, § 112 (2010). 
would also allow, in some cases, reimbursement of the dissidents' election contest expenses. ${ }^{16}$

The institutionalization of public company ownership and regulatory actions that empower shareholders have important consequences for corporate governance. Under the standard agency theory guiding efforts to empower shareholders, increased monitoring by shareholder-principals of manager-agents will reduce agency costs created by management shirking and expropriation of private benefits (through, for example, high compensation and perquisites). The SEC's regulatory support of a shareholder primacy model supported by agency theory is unsurprising. Subsidization of investor empowerment through regulatory action aligns with the SEC's mission of investor protection and shareholder primacy. With the shareholders deemed to act as a collective principal and management serving as the shareholders' agent, increasing shareholder power is a natural regulatory posture. But taken as a whole, increasing institutionalization and pro-shareholder regulations create a governance dilemma: although shareholder power may result in reduced agency costs due to management empire-building, other agency costs are created that may reduce the effectiveness of or even outweigh the gains from shareholder power.

As shareholders have increased their influence over corporate decisionmaking and policy, evidence of their activities suggests that often they do not act as a collective principal, that powerful shareholders are able to use their influence to seek rents at the expense of other shareholders or other corporate constituencies, and that corporations often adopt inefficient corporate governance mechanisms that align with influential shareholder preferences. The potential for inefficiencies and rent-seeking calls into question the expansion of shareholder power under the current regulatory model and raises the question of how existing shareholder power and influence should be regulated. Although shareholder power is often justified by reference to agency theory, the simple principal-agent model on which shareholder empowerment is based begins to collapse under the weight of these questions.

This Article offers an alternative model: a common agency theory for public corporations. A common agency is created when multiple principals influence a single agent; in the case of a corporation, common agency describes a shareholder/management relationship in which multiple shareholders with competing preferences exert influence on corporate management. The common

16. See id. $\$ 113$. 
agency theory set out in this Article provides several important contributions to the literature on corporate governance and shareholder empowerment. First, the theory provides a more complete explanation of the motivations for and outcomes of shareholder activism, including the activities of governmental owners, large institutional investors, and "social" investors. Second, the theory helps to delineate more clearly the costs and benefits of increasing shareholder power. Finally, building on these findings, the theory suggests possible regulatory changes to ensure that the benefits of shareholder activism outweigh its costs.

The Article proceeds in several steps. Part I describes how common agency often arises in public corporations. Common agency will be defined by two conditions. The first condition is that shareholders have heterogeneous interests-in other words, varying preferences as to how, when, and even whether share price (as a measure of shareholder wealth) should be maximized, and how shareholder wealth should be allocated among shareholders. The second is the ability of at least some shareholders to influence corporations to make decisions based on the shareholders' particular preferences. Taken together, these two conditions create a common agency relationship between management and a set of diverse shareholders, in which these shareholders lobby a common agentmanagement-to effect their heterogeneous and often competing preferences.

Part II of this Article reviews recent research on investor activities and argues that, while increasing shareholder power may decrease certain agency costs caused by management expropriation, common agency theory predicts that it may also increase other agency costs. As theory and empirical findings suggest, shareholders will seek to maximize their own utility, often at the expense of other shareholders or corporate stakeholders. Part II discusses how influential shareholders may extract private benefits from the corporation, incur and impose lobbying costs, and pressure corporations to adopt inapt corporate governance structures.

Part III turns to the role of regulators in addressing the impact of a common agency on public corporations: How will the corporation and the majority of its shareholders restrain opportunistic behavior by an influential minority of shareholders? A reversal of some of the regulatory subsidies that help foster common agency may be preferable to accretive regulation, but is probably unlikely in the current regulatory environment. Nevertheless, a common agency analysis argues against further expansion of shareholder power without appropriate regulation of how that power is used. Part III 
evaluates fiduciary duties and disclosure as a means to regulate shareholder power and influence. Increasing shareholder influence may justify the imposition of fiduciary duties on activist minority shareholders, as some have argued, but existing state fiduciary standards and modifications to the SEC's disclosure regime could also regulate common agency costs. This Article proposes disclosure requirements designed to preserve the positive effects of shareholder activism, such as the reduction of board and management agency costs, while also reducing common agency costs created by influential shareholders.

\section{COMMON AGENCY THEORY AND ITS APPLICATION TO PUBLIC CORPORATIONS}

Under a classic theory of the firm, agency costs in the corporate context increase as ownership is separated from control. ${ }^{17}$ As the manager's ownership of shares in the firm decreases as a percentage of the total, the manager will bear a diminishing fraction of the costs of any nonpecuniary benefits he takes out in maximizing his own utility. ${ }^{18}$ To prevent the manager from maximizing his utility at the expense of the shareholders, shareholders will seek to constrain the manager's behavior by aligning the manager's interests with the shareholders' interests. ${ }^{19}$ The costs of aligning interests (as well as the failure to adequately align interests) are collectively called agency costs and fall under three general categories. ${ }^{20}$ Monitoring costs refer to the costs incurred in limiting the opportunities for managers to capture benefits at the expense of shareholders. ${ }^{21}$ Such costs might include budget restrictions and internal and external auditing. ${ }^{22}$ The costs of providing ongoing disclosures are also a type of monitoring cost. Bonding costs are the costs managers incur as a guaranty to shareholders that the manager will limit his or her own utilitymaximizing activities, such as contractual limitations on the manager's decisionmaking power. ${ }^{23}$ Finally, costs associated with any divergence between the interests of the principal and the agent,

17. Michael C. Jensen \& William H. Meckling, Theory of the Firm: Managerial Behavior, Agency Costs, and Ownership Structure, 3 J. FIN. ECON. 305 (manuscript at 1), available at http://papers.ssrn.com/sol3/papers.cfm?abstract_id=94043\#\# (1976).

18. Id. at 17 .

19. Id. at 4 .

20. Id.

21. Id.

22. Id. at 26 .

23. Id. at 29 . 
despite the monitoring and bonding efforts to align their interests, are referred to as residual losses. ${ }^{24}$

Discussion of agency costs in the corporate context typically focuses on agency costs relating to executive compensation and management perquisites. ${ }^{25}$ Federal regulators have focused on executive compensation in recent years, and many regulatory initiatives have generally focused on management accountability as a means to reduce agency costs. In these regulatory efforts and in supportive academic commentary, shareholders are almost universally assumed to behave according to a central, common goal: shareholder wealth maximization. Under this view, shareholders collectively act as a unified principal, and agency problems between managers and shareholders are resolved within a simple two-party, principal-agent framework. The simple principal-agent model provides a useful and flexible framework for studying a variety of important economic phenomena, including those within the corporation. ${ }^{26}$ But as B. Douglas Bernheim and Michael Whinston noted in their seminal article on common agency, "[f]requently... the action chosen by a particular individual (the agent) affects not just one, but several other parties (the principals), whose preferences for the various possible actions typically conflict." 27 In such cases, an agent is considered the common agent of the multiple principals. As indicated in the diagram below, common agencies are thus distinguished from single-principal agency relationships (as is typically assumed in applying agency theory) or a collective principal agency relationship in which a number of individuals collectively act and are collectively served within the principal-agent relationship. ${ }^{28}$

24. Id. at 5 .

25. See, e.g., Lucian Arye Bebchuk \& Jesse M. Fried, Executive Compensation as an Agency Problem, 17 J. ECON. PERSP. 71 (2003); Geoffrey S. Rehnert, The Executive Compensation Contract: Creating Incentives to Reduce Agency Costs, 37 STAN. L. REV. 1147 (1985).

26. B. Douglas Bernheim \& Michael D. Whinston, Common Agency, 54 EconometricA 923, 923-942, (1986).

27. $I d$.

28. The typology set out here and in the accompanying figure is derived from Daniel $\mathrm{L}$. Nielsen \& Michael J. Tierney, Principals and Interests: Common Agency and Multilateral Development Bank Lending, 2008 Midwest Pol. Sci. Assoc. Meeting. (April 2008). 
Figure 1: Types of Agency Relationships

Single Principal

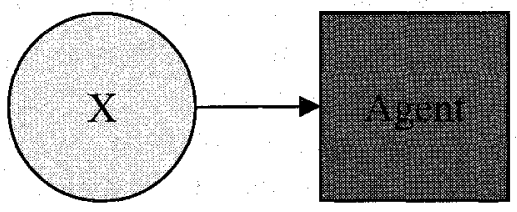

Collective Principal

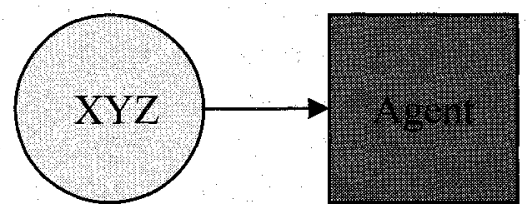

\section{Common Agent of Multiple Principals}

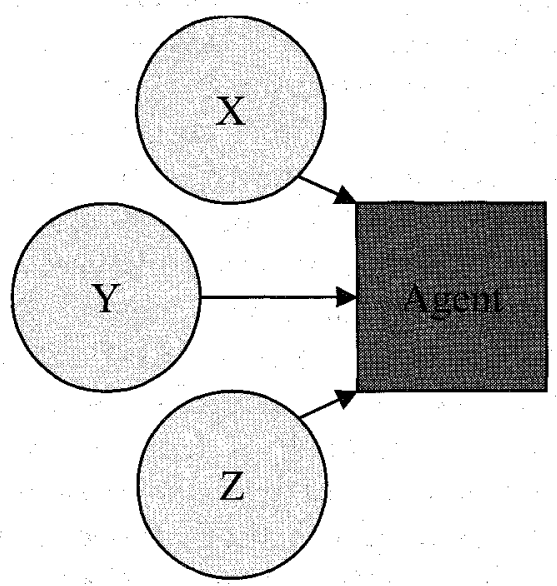

Common agency theory has been used to describe a variety of principal-agent relationships, and game theorists have relied on common agency theory to model these relationships. For example, political economists apply common agency to the analysis of governmental relationships ${ }^{29}$ since a government agency may answer to the executive branch, the legislative branch, and the courts. ${ }^{30}$

29. See, e.g., Avinash Dixit, Power of Incentives in Private Versus Public Organizations, 87 AM. ECON. ASS'N PAPERS AND PROC. 378, 378-379 (1997).

30. Avinash Dixit argues that "a distinct feature of government bureaucracies is that they must answer to multiple principals," and "the executive, . . . Congress, courts, media and organized lobbies, all have a say." Id. at 378-79. Dixit, like others, has also considered the application of common agency theory to corporations, but he and others have assumed homogeneity of shareholders interest, and so have discussed common agency theory's application to stakeholder theory:

Recently in the United States and the United Kingdom a concept of "stakeholder economy" has evolved, according to which firms are supposed to be responsible not merely to their shareholders, but to a more varied collection of "stakeholders": 
Common agency theory may be applied to corporate law in two ways. First, managers may be considered agents not just to shareholders but also to all of the various stakeholders of the corporation, including employees, suppliers, and creditors. While these diverse stakeholders have many common interests, they also have competing, heterogeneous interests. Consider the interests of shareholders and the interests of workers: shareholders are typically understood to have a goal of stock price value maximization, while each worker will normally be concerned with maximizing his or her own utility. These goals conflict when, for example, a company is deciding whether to close an underperforming factory. Although workers may be incentivized through stock options to share a stock price maximization goal, we should not expect incentive compensation to eliminate all differences in interest between workers and stockholders. To the extent that both stockholders and workers are able to influence a board of directors to make decisions that favor the interests of one constituency over the other, the directors act as a common agent to both constituencies. ${ }^{31}$ However, the U.S. corporate governance framework is increasingly driven by federal regulation that adopts a shareholder primacy model favoring shareholders against other corporate constituencies. As a result, although common agency theory may have useful normative implications for stakeholder theories of the corporation, it is of limited utility as a descriptive theory of management's relationship with corporate stakeholders.

Second, as described in this Article, common agency theory may be applied to the public corporation when managers are answerable to and influenced by multiple shareholders with heterogeneous interests. ${ }^{32}$ Regulators and academics typically regard

workers, creditors, the local community, and so forth. If this comes to be accepted and built into the legal and organizational structure of corporations, all these groups will become principals, with their firms as common agents. Such "politicization" of firms will further lower the power of incentives, which is already low for other reasons.

Id. at 381 .

31. This raises the issue of the "constituency director"-a director whose board membership is directly attributable to particular constituencies. See Joseph Hinsey, The Constituency Director, HARVARD LAW SCHOOL FORUM ON CORPORATE GOVERNANCE AND FINANCIAL REGULATION, http://blogs.law.harvard.edu/corpgov/2008/01/14/the-constituency-director/ (last visited Aug. 31, 2010) (describing the divide between the reality for constituency directors, in which they vote and advocate for their constituents, and the legal duty of directors that requires undivided loyalty to the corporation and shareholders generally, and arguing that constituency directors should only be able to advocate for their constituents after full disclosure, but that they must represent the interests of all shareholders when voting).

32. Common agency theory has not been explicitly applied to the management-shareholder relationship in the legal academic literature, although Jeffrey Gordon recognized nearly twenty years ago that shareholders act as "multi-principals", and his excellent work on a game-theoretic approach to shareholder voting is not only still vibrant but increasingly relevant as shareholder 
management as the agent and shareholders as a unified principal. ${ }^{33}$ Federal regulation of public corporations is thus assumed to operate under a collective principal agency theory. However, in the case of public corporations in which multiple shareholder groups express competing preferences, the simple principal-agent model-and a regulatory framework built around this simplified model-will ignore other types of agency costs that arise from shareholder activism. A common agency theory of public corporations provides a more accurate and functional explanation of management-shareholder relationships and, more importantly, should provide a better theoretical base for regulatory efforts to manage agency costs.

\section{A. Evidence of Common Agency in Public Corporations}

\section{Shareholder Influence in Public Corporations}

Shareholder influence takes a number of forms. In their survey of public pension fund activism, for example, Stephen Choi and Jill Fisch classified twenty-six types of activism that at least some of their surveyed funds engaged in occasionally or frequently. ${ }^{34}$ The most popular forms of activism, in which at least half of the funds were engaged frequently or occasionally, included: writing comment letters to the SEC; soliciting support for activities from other institutions (building coalitions); withholding votes from a management director candidate; signing comment letters to the SEC (as part of group); participating in corporate governance programs; participating in corporate governance organizations; and communicating with other institutions regarding corporate governance..$^{35}$ More than one-third of the funds also influenced managers more directly through letters or direct negotiations.

A small but active subset of shareholders also engages in proxy activism ${ }^{36}$ by submitting shareholder proposals. Shareholder proposals can be divided into two general types: corporate governance proposals

power increases. See Jeffrey N. Gordon, Shareholder Initiative: A Social Choice and Game Theoretic Approach to Corporate Law, 60 U. CIN. L. REV. 347 (1991). My approach in this Article differs in that I more directly apply the theory of common agency to the shareholder management relationship, and broaden the scope of the inquiry to cover shareholder influence generally, rather than focusing on shareholder voting.

33. Id. at 385 .

34. Stephen J. Choi \& Jill E. Fisch, On Beyond CalPERS: Survey Evidence on the Developing Role of Public Pension Funds in Corporate Governance, 61 VAND. L. REV. 315 (2008).

35. Id.

36. Id. Choi and Fisch report that 17.5 percent of public pension funds engage in proxy activism. 
and social proposals. With respect to corporate governance, investors have focused on a number of key issues in the past several proxy seasons.

First, shareholder activists have consistently made gains in recent years by convincing corporations to eliminate antitakeover measures that activists believe are often used as mechanisms for management entrenchment. ${ }^{37}$ For example, activists have been successful in reducing the number of companies with classified or staggered board structures. ${ }^{38}$ Classified boards typically have three classes of directors that are separated into staggered three-year terms, so that it is impossible to elect any more than one-third of the total number of directors in any given year. After pushing the issue for several years (aided by annual recommendations from proxy advisors), activists have succeeded in making annually elected boards the predominant form of board structure. Similar efforts were undertaken with majority voting proposals ${ }^{39}$ and proposals calling for the elimination of certain kinds of poison pills. Proposals dealing with executive compensation have been of particular importance to proxy advisors and many institutional investors in recent years. For example, in the last several years (prior to their mandatory imposition as a result of the Dodd-Frank Act), shareholder activists have put forward proposals that would provide for, among other things, "say-onpay" bylaw provisions and clawback provisions that would allow the company to recover compensation from executives in the case of certain events, such as a disclosure that compensation was earned as a result of the executive's misconduct. ${ }^{40}$ The election of directors appointed by minority shareholders provides another important example of shareholder influence through actual or threatened proxy power. The Wall Street Journal reports that from 2006 until the end of the 2008 proxy season, activists had been awarded board seats at 218 companies and notes that "[o]f those, just 28 came via proxy fights ... meaning boards are giving up seats without having officially lost them." ${ }^{41}$ The Wall Street Journal further states that activists "have

37. GEORgeson, 2007 ANNUAL Corporate GovernanCE REview 18 (2007).

38. Id.

39. Id. at 4-5. Majority vote provisions require a director candidate to have received a majority of affirmative votes in order to be seated. For a discussion of the various types of majority vote proposals and their merits, see William K. Sjostrom Jr. \& Young Sang Kim, Majority Voting for the Election of Directors, 40 CONN. L. REV. 459 (2007).

40. GEORGESON, 2009 ANNUAL CORPORATE GOVERNANCE REVIEW 4 (2009).

41. Dennis K. Berman, The Game: In Era of Activists, Look to Changes, WaLl ST. J., July 8, 2008 , at C1. 
already won or wrested concessions in nearly $60 \%$ of 78 completed or threatened proxy contests of 2008 , the highest percentage ever." 42

Shareholder proponents have been less successful in their efforts to promote social causes through the proxy process, although they have made some slow but steady gains. ${ }^{43}$ Some of the more successful proposals deal with environmental issues, such as a request that the board commission a study of the environmental impact of the company's operations. ${ }^{44}$

Although the proxy process is the most studied venue for shareholder activism, shareholders have also directly taken their case to other shareholders or to the public at large. Some of this activism is essentially political in nature. One of the most memorable examples of this type of public activism was the attempt to pressure South Africa into abandoning its apartheid regime by divestment from businesses with operations in South Africa. ${ }^{45}$ Corporate governance proposals may also be taken to the shareholders through public fora, such as by press release coupled with an SEC filing. In 2008, for example, activist investor Bill Ackman prepared a public presentation on how Target Corporation could improve its performance. The presentation had multiple audiences and goals. On the one hand, Ackman provided the board and management with a series of strategies to improve

42. Id.

43. RISKMETRICS GROUP, 2007 POSTSEASON REPORT 31.

44. Under the Bush administration, the SEC considered pushing back against non-binding shareholder proposals. In 2007, the SEC sought public comment on a number of proposals, three of which would have affected social proposal proponents particularly. According to ISS, "The SEC has asked whether boards should be allowed to opt out of non-binding proposals without obtaining investor approval if the company is incorporated in a state that would permit such a change. Second, the SEC asks whether companies should be allowed to institute electronic shareholder forums in lieu of non-binding proposals. Finally, the agency is seeking comment on whether to raise resubmission thresholds to ten, fifteen, and twenty percent. Such a change would primarily impact social resolutions, which historically have received less support than many governance proposals." Id. at 34 .

45. As a study conducted by Teoh, Welch, and Wazzan suggests, such activism often has more bark than bite:

[There is] no support for the common perception-and often vehement rhetoric in the financial media-that the anti-apartheid shareholder and legislative boycotts affected the financial sector adversely: the announcement of legislative or shareholder pressure had no discernible effect on the valuation of banks and corporations with South African operations or on the South African financial markets.

Siew Hong Teoh, Ivo Welch \& C. Paul Wazzan, The Effect of Socially Activist Investment Policies on the Financial Markets: Evidence from the South African Boycott, 72 J. BUS. 35, 79-83 (1999). The authors suggest that the lack of a significant effect is attributable to a reallocation from "socially responsible" to indifferent investors. The authors are careful not to suggest that the boycott was a failure, however, since it may have "been effective in raising the public moral standards or public awareness of South African repression." Id. at 83. As a type of punitive measure, the boycott does not appear to have been a success. 
performance; on the other hand, public disclosure of the presentation alerted other shareholders to Ackman's vision of the company and created an expectation of a board and management response to Ackman's ideas for value-creation. ${ }^{46}$

These forms of activism share a common characteristic: they are all public-obviously intended to be visible to other shareholders. In the case of a fund, these forms of activism are subject to scrutiny by the beneficial owners of the fund for whom the fund managers act as fiduciaries. However, many activist shareholders are also engaging directors directly through non-public communications. According to Institutional Shareholder Services ("ISS"), such activism has increased significantly in recent years, with boards and management more willing to engage in dialogue with investors. ${ }^{47}$ One method of measuring an increase in dialogue between management and investors is through the amount of withdrawn proposals in a proxy season. While shareholders put forward hundreds of proposals to be included in the annual proxy statement of the company, only a fraction is ultimately included in the proxy statement. Some are proposals excluded through the application of the shareholder proposals rules under Exchange Act Rule 14a-8 (typically as a result of a company objection and request of a no-action letter from the SEC). Many proposals, however, are voluntarily withdrawn by the shareholder proponents and omitted from the final proxy statement. Often, shareholders withdraw the proposal after a discussion with management that results in either management's agreement to implement a change in policy in accordance with the shareholders' proposal or to offer a proposal that satisfactorily replicates the shareholder proposal. Reviewing the 2007 proxy season, for example, RiskMetrics reported that "[i]nvestors and U.S. corporate issuers came together as never before in 2007 to address a wide range of concerns and to better align views on corporate best practices." 48 Richard Ferlauto, director of corporate governance and pension investment at the American Federation of State, County, and Municipal Employees ("AFSCME"), stated that "[t]here's been an unprecedented level of engagement between companies and shareholders. Engagement is

46. See Why Activist Shareholders Are Gaining Support, THEDEAL.COM (on file with author).

47. GeORgeson, supra note 37; GeORgeson, 2008 AnNual CoRporate Governance REVIEW (2008); see also RISKMETRICS GROUP, supra note 43. While this is explained partially by the increase in activism generally, especially as practiced by many hedge funds, the increase in this type of activism may also be attributable in part to an increase in the number of independent directors.

48. RISKMETRICS GROUP, supra note 43 , at 43 . 
now part of the landscape."49 Amy Goodman, a prominent practitioner, reported that the settlements achieved between management and shareholders on political contributions were a "perfect example of engagement.... Companies and investors agreed this year to a scalable solution on political contribution disclosures whereby smaller companies would have less onerous disclosure demands." 50

While some explain the increase in engagement as a result of a growing increase in votes that support many shareholder proposals (with boards and especially independent directors not wanting to ignore the wishes of a majority of shareholders on a given governance issue), Ferlauto suggested the SEC's new compensation rules are the more likely factor. He argued that boards were motivated to engage in order to "mollify pay-related concerns and preempt negative publicity,"51 an explanation which suggests that managers and directors are willing to negotiate on issues of less personal importance, though perhaps not less relevant to the governance of the corporation, than issues of prime personal importance like pay.

In reviewing shareholder proposals from 2006 through 2008, Georgeson Shareholder also noted an increase in withdrawn proposals, which they believe suggests an increase in this type of engagement with shareholders. ${ }^{52}$ This phenomenon holds across all key types of proposals reflected in Georgeson's data. For example, while management may have been expected to be more likely to engage with shareholders on "hot" governance topics, such as majority voting, management also engaged more shareholders on issues that typically receive significantly less than a majority of votes, such as proposals related to sustainability, climate change, and political contributions. ${ }^{53}$ Typically, however, management will be less willing to engage on issues in which it is clear that the shareholder proposal will be viewed favorably by a very small percentage of the outstanding share ownership. ${ }^{54}$

\footnotetext{
49. Id.

50. Id.

51. Id. at $43-45$.

52. Georgeson's data also includes proposals that were omitted because the proposals could be excluded under SEC rules. Given the relatively few exclusions that are granted by the SEC, this is likely a small percentage of the total "omitted" category. However, precise percentages are not available because Georgeson does not provide subcategories for the omitted data.
}

53. RISKMETRICS GROUP, supra note 43 , at 31.

54. See Subodh Mishra, Analysis: Forces Fueling Engagement to Grow in 2008, RISKMETRICS GROUP BLOG (Aug. 2, 2007), http://blog.riskmetrics.com/gov/2007/08/analysisforces-fueling-engagement-to-grow-in-2008submitted-by-subodh-mishra-managing-editor.html. 
A study of the corporate governance initiatives of TIAACREF ${ }^{55}$ one of the world's largest private asset managers, ${ }^{56}$ reveals that "behind-the-scenes" activism coupled with proxy proposals can be an extremely effective tool for shareholder activists seeking to effect corporate policy changes. Willard Carleton, James Nelson, and Michael Weisbach reviewed private negotiations covering the years 1992 through 1996 between TIAA-CREF and targeted firms in its portfolio. They found that of the forty-five firms TIAA-CREF contacted, it reached agreements with forty-two of the forty-three firms that were not acquired during the course of negotiation. ${ }^{57}$ Importantly, the authors note that TIAA-CREF obtained such impressive results despite reaching a majority vote on a formal shareholder proposal in only one case. ${ }^{58}$ In most cases (seventy-one percent), the target firm came to agreement with TIAA-CREF before the proposal came to a vote. ${ }^{59}$

The uses of shareholder influence described here provide only a brief outline of the ways in which shareholders increasingly influence corporate affairs. The ability of shareholders to influence public corporations is well documented, ${ }^{60}$ and is, of course, the intended consequence of shareholder empowerment efforts by regulators, proxy advisors, and powerful institutional investors. The next Section describes the second condition for common agency in public corporations-the heterogeneity of interests among shareholders-and describes both the nature of these heterogeneous interests and also how these interests are expressed in corporate policy and governance through the efforts of influential investors.

\section{Heterogeneity of Interests Among Public Company Shareholders}

As noted above, the standard agency model of corporate relationships has treated shareholders as a unified body with respect to a single corporate goal: shareholder wealth maximization. However, there are a number of reasons to doubt that shareholders are unified as collective principals. First, shareholders may have a variety of reasons for promoting certain corporate transactions or policies.

55. Willard Carleton et al., The Influence of Institutions on Corporate Governance Through Private Negotiations: Evidence from TIAA.CREF, 53 J. FIN. 1335 (1998).

56. See GLOBAL INVESTOR, TOP 100 LARGEST ASSET MANAGERS, available at http://www.riskcenter.com.tr/risknews/risknewsfiles/assetmanagementdunyasiralamasi.pdf.

57. Carleton et al., supra note 55, at 1336.

58. Id.

59. Id.

60. See infra Part I.A.2.b. 
Under a system of relatively weak shareholder power, it matters little whether shareholders hold heterogeneous views; they have too little influence individually to force managers to make change, and so only shareholder initiatives that generate broad support could force action by the company. ${ }^{61}$ However, as shareholder power increases, the likelihood that powerful shareholders will be able to express such preferences generally increases.

Looking first to shareholder proposals as one indication of shareholder preferences, it is clear that at least a small but active subset of shareholders holds non-wealth-maximizing preferences. Publicly traded corporations receive a significant percentage of shareholder proposals each year that are not based on financial motivations, but rather on what the shareholder proponents consider to be moral or ethical concerns. ${ }^{62}$ These shareholders typically receive little support from other shareholders and are relatively less likely to influence managers, given their typically low levels of share ownership. ${ }^{63}$ Setting such investors aside, even if we were to accept that all shareholders share a long-term shareholder wealth maximization focus, shareholder proposals focusing on corporate governance issues reveal that shareholders have very different beliefs about what contributes to long-term wealth maximization. ${ }^{64}$ Regardless of whether one focuses on shareholder proposals that reflect social concerns or proposals that reflect corporate governance concerns, shareholder voting reveals little overall interest in most shareholder proposals, even among shareholders who do not have any apparent conflicts that would cast doubt on their voting decisions. ${ }^{65}$ Many shareholders do not support other shareholders' initiatives because they tend to vote reflexively according to management

61. George Dent makes this argument, among others, in a recent paper. George Dent, The Essential Unity of Shareholders and the Myth of Short-Termism, 35 DEL. J. CORP. L. 97, 107 (2010). I do not dispute that he is right that most shareholders will not support value-decreasing social proposals or corporate governance measures. However, the evidence set out in this Article suggests that shareholders need not gain significant support from other shareholders through a proxy vote (except perhaps with social welfare-type proposals) in order to influence corporate management.

62. See, e.g., RISKMETRICS GROUP, 2009 POSTSEASON REPORT 15-16.

63. Some shareholders hold shares simply to provide themselves with another forum in which to air their grievances against the company. It is possible that even shareholders who own few shares are able to promote change in corporate behavior by waging a public relations campaign against the corporation, with shareholders' proposals as a minor front in a larger campaign. The focus of this Article is not on this type of public relations activity, however, but on the use of shareholder power. Many social activists are influential because of their public status, but not because of their shareholder status.

64. See, e.g., RISKMETRICS GROUP, supra note 62, at 5.

65. Id. 
recommendation. ${ }^{66}$ However, some shareholders likely vote against shareholder proposals simply because shareholders differ in how they believe the corporation should be managed. Such corporate policy preferences may not have mattered under a norm of shareholder passivity in which shareholders would express their displeasure by selling stock; however, in an era in which shareholders are increasingly successful in lobbying for corporate change, these differences create costs that undermine the utility of shareholder activism.

In this Section, I will describe several broad dimensions of potential differences among shareholders: heterogeneity of interests in corporate goals (i.e., interests that may diverge from a shareholder wealth maximization norm); heterogeneity of interests in appropriate corporate governance initiatives; and heterogeneity of investor expectations. Although shareholders may hold heterogeneous preferences in other ways or for other reasons, the Article focuses on these dimensions because they are the most likely to motivate shareholder activism.

\section{a. Heterogeneity in Social Preferences}

Certain investors own shares solely for the purpose of using the proxy process as a means of publicizing the investor's policy preferences with the hope of influencing a corporation to adopt those preferences, even if the preferences are inconsistent with shareholder wealth maximization. People for the Ethical Treatment of Animals ("PETA"), for example, has "purchased shares in companies where the inhumane treatment of animals came to [its] attention," and "has exercised its right as a stockholder and filed shareholder proposals with many companies." 67 PETA also encourages its supporters to propose shareholder resolutions to address "the replacement, protection, and humane treatment of animals used in pharmaceutical testing, in the food industry, in pet-food testing, and in chemical testing, to name a few."68 Such investors, however, are rarely able to make significant changes in corporate activities, and if changes do occur, the investor's share ownership is likely to have been an insignificant factor in the corporation's decision-share ownership simply provides another front on which to fight the campaign. The

66. Parades, supra note 8.

67. PETA's Shareholder Resolution Campaign, PEOPLE FOR THE ETHICAL TREATMENT OF ANIMALS, http://www.stopanimaltests.com/f-shareRes.asp (last visited Aug. 31, 2010).

68. Id. 
likely effect of such activism is to draw attention and increased financial support to the social cause, rather than bring about a change in corporate practices.

Purely social investors tend to own very small stakes and therefore lack a credible market threat to management; managers are more likely to respond to social investors qua public activists rather than because of their shareholder status. As a general matter, the more significant the shareholder is in terms of percentage ownership, the more influential the shareholder will be with management. Even a shareholder with a relatively small but non-negligible ownership percentage-say, between two and five percent-may have a significant impact on corporate policies. While it is very unlikely that a shareholder with purely nonfinancial motives would invest at such levels, some shareholders invest with what may be characterized as mixed motives-they are largely concerned with financial returns, but are also likely, for various reasons, to support certain social causes.

One type of investor that often displays mixed motives is the public pension fund. A number of commentators, led by Roberta Romano, have addressed potential conflicts of interest that may affect investment by such funds, including "political pressure to accommodate investment and voting policies to local considerations, such as increasing in-state employment."69 Governmental owners, including sovereign wealth funds, ${ }^{70}$ may also hold mixed investment motives. Some of the sovereign controllers of these funds may be political and economic rivals to the United States, which creates a concern that the sovereign wealth fund will be used for a variety of purposes adverse to the interests of the United States. For instance, the fund could be used to take control of an enterprise that controls or has access to technology that affects national security. Alternatively, the fund could simply use its controlling share to gain access to technology that could be exploited by the sovereign's domestic industries. However, many of these risks, especially those related to national security, are mitigated by a collection of regulations, including the regulations of the Committee on Foreign Investment in the United States ("CFIUS"). ${ }^{71}$ Rather, the greatest influence by a

69. Roberta Romano, The Politics of Public Pension Funds, 119 Pub. INT. 42, 43 (1995).

70. For a discussion of the investment motives of sovereign wealth funds, see Paul Rose, Sovereigns as Shareholders, 87 N.C. L. REV. 83, 99-102 (2008).

71. While the CFIUS regulations take effect only if the sovereign wealth fund exercises control over the firm, control is broadly defined and includes some types of direct influence over corporate affairs. Besides the potential application of CFIUS, there are a number of economic justifications for passivity that make sovereign wealth funds unlikely to attempt to exert significant influence over public corporations. See id. 
governmental owner over U.S. public corporations has come from the U.S. government itself. A conspicuous example was the successful effort of Representative Barney Frank, chairman of the House Financial Services Committee that helps oversee the Troubled Asset Relief Program ("TARP"), to convince General Motors to keep in operation a plant in his district that the automaker had determined to close. ${ }^{72}$

A difficulty in assessing the impact of social and mixed-motive investment is that it is often difficult to distinguish between social and corporate governance goals. Is high executive pay a bad thing because it provides evidence of managerial empire building or because it reveals social stratification? The American Federation of Labor and Congress of Industrial Organizations ("AFL-CIO") seems to suggest that both of these reasons support action on executive pay:

\begin{abstract}
Americans have expressed outrage as CEOs and other executives responsible for the financial crisis have pocketed millions of dollars from bonuses and golden parachutes [agency costs]. CEO perks alone in 2008 amounted to an average of $\$ 364,041-$ or nearly 10 times the median salary of a full-time worker [social stratification]. ${ }^{73}$
\end{abstract}

The social preferences of influential investors likely have a relatively small effect on the decisions and policies of most public corporations. However, in his recent survey of the corporate governance effects of proxy voting, David Yermack noted that "[s]ocial investors have grown numerous enough potentially to challenge the governance and compensation practices of certain companies."74 While social investors do not enjoy (and probably do not expect) significant success with social, wealth-decreasing shareholder initiatives, Yermack noted that a firm could face a concerted voting campaign by social investors: "For instance, an environmentally-conscious hedge fund could accumulate enough votes to unseat the directors of a highpolluting electric utility, perhaps with voting support from the endowment funds of universities and conservationist organizations."75 Such a possibility suggests the difficulties created by common agency in the corporate context; "[h]ow managers would balance the interests of these voters with those of ordinary shareholders who simply seek to

72. Michael O'Brien, Barney Frank Convinces GM CEO to Keep His District's Plant Open, HrLL (June 4, 2009), http://thehill.com/blogs/blog-briefing-room/news/lawmaker-news/35028. barney-frank-convinces-gm-ceo-to-keep-his-districts-plant-open.

73. 2009 Executive Pay Watch, AFL-CIO, quoted in Why Unions Are Important, GRASS RoOTS PRESS, http://www.grassrootspress.net/code/labor.html (last visited Sept. 17, 2010).

74. David Yermack, Shareholder Voting and Corporate Governance 30 (Mar. 17, 2009) (working paper), available at http://ssrn.com/abstract=1523562.

75. Id. 
make profits would raise novel legal and ethical questions." 76 Despite this potential, however, social activism appears to be more of an annoyance to corporate management than a major threat to the shareholder wealth maximization norm.

\section{b. Heterogeneity in Corporate Governance Preferences}

Although heterogeneous social preferences likely play a minor role in corporate decisionmaking, of more significance, and with better evidentiary support for their influence on corporate decisionmaking, are the effects of heterogeneous corporate governance preferences among shareholders. A number of recent studies confirm that shareholders hold heterogeneous views on corporate governance matters and that some shareholders are able to influence corporate governance changes that may not be desirable to other shareholders.

In a survey of institutional investors, Joseph McCahery, Zacharias Sautner, and Laura Starks found that investors have diverse preferences over governance mechanisms and that their preferences affect their investment decisions and their decision to engage in activism. ${ }^{77}$ Hedge funds tend to view equity ownership by managers of highest importance. ${ }^{78}$ Insurance companies, on the other hand, value a high free float, which provides the company the possibility of liquidating shares easily. ${ }^{79} \mathrm{Mutual}$ funds find both equity ownership by managers and transparency about holdings of large shareholders to be most important, ${ }^{80}$ while pension funds are most concerned about ownership concentration, board independence, and a high free float. ${ }^{81}$ The authors also found that the majority of the institutional investors who responded to their survey were willing to engage in shareholder activism, with the most likely methods of activism being to vote with their feet by selling their shares, to vote against the company at the annual meeting, and to engage in discussions with the firm's executives. ${ }^{82}$ A substantial number of the surveyed investors would consider contacting the firm's directors to

76. Id.

77. Joseph McCahery et al., Behind the Scenes: The Corporate Governance Preferences of Institutional Investors 18 (Mar. 15, 2010) (working paper), http://papers.ssm.com/sol3/ papers.cfm?abstract_id $=1571046$.

78. Id. at 13 .

79. Id.

80. Id.

81. Id.

82. Id. at 23. 
discuss their concerns, ${ }^{83}$ implying that "behind-the-scenes shareholder activism may be more prevalent than previously thought." 84

Johan Sulaeman has also examined heterogeneous preferences among investors and studied the effects of these preferences on firm decisions. ${ }^{85} \mathrm{He}$ found that heterogeneous investor preferences are related to subsequent changes in the financial and investment policies of firms. ${ }^{86}$ In particular, firms are more likely to decrease their leverage ratios if their current leverage is higher than the preferences of their institutional shareholders. Firms are also more likely to increase their investment if their current investment ratio is lower than the preferences of their institutional shareholders. ${ }^{87}$ Sulaeman concluded that "overall, the evidence suggests that the preferences of institutional shareholders are important determinants of corporate policies." 88

Research by Henrik Cronkvist and Rüdiger Fahlenbrach ${ }^{89}$ also suggests that large shareholders are both influential and heterogeneous in their interests. For hedge funds and other regular activists, such as pension funds, they documented significant shareholder influence over policies regarding research and development, financial policies such as dividends, and CEO compensation. ${ }^{90}$ Surprisingly, they found significant effects on investment and financial policies by mutual funds, which are typically viewed as the prototypical large, passive investor..$^{91}$ For leveraged buyout firms, they also found significant effects related to capital expenditures, leverage ratios, and cash holdings, and they reported significant effects related to investment, research and development policy, and cash holdings for venture capital firms. ${ }^{92}$ Cronkvist and Fahlenbrach concluded that "there is significant variation in beliefs, skills, and preferences also among blockholders within the same category of large shareholders." 93

\footnotetext{
83. Id.

84. Id.

85. Johan Sulaeman, Do Shareholder Preferences Affect Corporate Policies? 9-12 (Mar. 16, 2010) (working paper), available at http://ssrn.com/abstract=1102005.
}

86. Id. at $1-2$.

87. Id.

88. $I d$.

89. Henrik Cronqvist \& Rüdiger Fahlenbrach, Large Shareholders and Corporate Policies, 22 REv. FIN. STUD. 3941 (2009).

90. Id. at 3943 .

91. Id. at 3958 .

92. Id.

93. Id. 
Even where there may be general agreement among shareholders on corporate governance policies, shareholder interests may still conflict with respect to a particular acquisition decision. Jarrad Harford and Dirk Jenter ${ }^{94}$ found that when a company is considering an action that affects other firms in its shareholders' portfolios, shareholders with heterogeneous portfolios may disagree about whether the company should proceed with the transaction. ${ }^{95}$ Using takeover data from 1984 through 2002, they found that this effect is "measurable and potentially large in the case of corporate acquisitions, where bidder shareholders with holdings in the target want management to maximize a weighted average of both firms' equity values." 96 For institutional investors, such cross-holdings often factor in a significant number of deals. ${ }^{97}$ Their research suggests that managers consider cross-holdings when identifying potential targets and that they "trade off cross-holdings with synergies" when selecting potential targets. ${ }^{98}$ Overall, Harford and Jenter concluded that "conflicts of interests among shareholders are sizeable and, at least in the case of acquisitions, affect managerial decisions,"99 and that "[d]iversified shareholders prefer corporate policies which maximize their portfolio values to policies which narrowly maximize the value of individual firms, and shareholders with different portfolios disagree about which actions firms should pursue."100

\section{c. Heterogeneity in Investor Expectations}

Heterogeneous investor expectations are related to (and perhaps often explain) differences in corporate governance preferences. Under certain conditions, investors may differ in the valuations of the firm, and these differences may manifest themselves in shareholder voting and decisions to attempt to influence a company to act in accordance with investor preferences. While the Efficient Capital Markets Hypothesis ("ECMH") suggests that the market price for a company's stock should not deviate significantly from fundamental value, stock price bubbles driven by overly optimistic

94. Jarrad Harford et al., Conflicts of Interests Among Shareholders: The Case of Corporate Acquisitions (Mass. Inst. Tech., Sloan Research Paper No. 4653-07; Rock Ctr. for Corporate Governance, Working Paper No. 35, 2009), available at http://ssrn.com/abstract=947596.

95. Id.

96. Id.

97. Id.

98. Id.

99. Id.

100. Id. at 25 . 
investor expectations may yet distort corporate policies and decisions. William Bratton and Michael Wachter provided a detailed review ${ }^{101}$ of the heterogeneous expectations literature describing this phenomenon. To summarize their argument, heterogeneous expectations models describe two components of stock prices: a fundamental value component and a speculative component that provides the investor the option to sell his or her stock to a more optimistic investor. ${ }^{102}$ As a result, "even in equilibrium, the stock price may exceed the valuation of the most optimistic investor."103

The heterogeneous expectations models predict that "[i]ncreases in the speculative component of the stock price provide little or no information on fundamental value enhancement."104 Therefore, a shareholder that votes based on market price information could be greatly misled in supporting management, and "[s]hareholder voting would reward those companies whose prices had an increased speculative component."105 This distorts incentives for management so that managers attempting to obtain shareholder support for business decisions, including executive compensation, "would have an incentive to skew business policy in directions that excited speculative reactions in the market." 106

Investment strategies may also be affected by heterogeneous expectations. A study by John Asker, Joan Farre-Mesna, and

101. William W Bratton \& Michael L Wachter, The Case Against Shareholder Empowerment, 158 U. PA. L. REV. 653 (2010).

102. Id at $693-695$.

103. Id. at 707. Bratton and Wachter are careful to note that the models do not assume that all securities are systematically mispriced. Heterogeneous expectations models do not invalidate the ECMH, but instead help reconcile the ECMH with the observation of stock price bubbles. They note:

First, there is no claim that financial markets always operate in a state where heterogeneity of expectations causes prices to diverge from fundamental value expectations. Heterogeneity is likely to occur when there is a change in technology, when glamour companies emerge, or when companies running newer businesses with less established track records become an important part of the market.

Second, the literature yields a picture of bubbles that can be read together with semi. strong ECMH. . . . [A] bubble can only be identified after it has burst; rapidly rising stock prices do not constitute a bubble unless or until followed by a sharp decline or collapse. Ex-post identification is not problematic for semi-strong efficiency, however, since there is no claim that a bubble can be identified ex ante. It follows that there is no implicit claim that a contrarian trading strategy can be developed that yields reliable profits from a bubble.

Third, the models do assume constraints on short selling that prevent arbitrageurs from eliminating upward bias in the stock price stemming from optimistic purchases.

Id. at $707-08$.

104. Id. at 709 .

105. Id.

106. Id. 
Alexander Ljungqvist compared private and public firms and the results of their respective investment strategies. ${ }^{107}$ They found that managers at public firms generally invest less and are less responsive to investment opportunities than their counterparts at private firms. They concluded that the concern for public companies' current stock price causes managers at public firms to take a short-termist approach at the expense of long-term investment. ${ }^{108}$

Recent literature on heterogeneous expectations literature also helps explain why some shareholders and managers take a shorttermist approach under certain conditions, even though this approach may ultimately be harmful to other shareholders. Heterogeneous expectations models predict that during the time in which a speculative bubble is growing, managers attempting to maximize the stock price for the current shareholders should sell additional overpriced stock, which has the effect of lowering the company's cost of capital, and then approve increased capital expenditures. ${ }^{109}$ Stavros Panageas argued that this investment increases the fundamental value of the corporation according to the beliefs of the current owners (the high stock price indicating a high present value of growth opportunities), and also increases the speculative component of the stock price, which allows the investors to capture a larger resale value when they sell their stock. ${ }^{110}$ Bratton and Wachter identified a similar conclusion in works by José Scheinkman and Wei Xiong, ${ }^{111}$ and Patrick Bolton. ${ }^{112}$ The models suggest that "it is in the interests of current shareholders for managers to have a short-termist view so as to maintain the speculative element in the stock price and give the current shareholders the possibility of selling to even more optimistic investors."113

The evidence outlined in the preceding sections indicates that investors often hold heterogeneous views, and some investors-

107. John Asker, Joan Farre-Mesna \& Alexander Ljungqvist, Does the Stock Market Harm Investment Incentives? 2 (Eur. Corporate Governance Inst., Finance Working Paper No. 282, 2010), available at $\mathrm{http}: / / \mathrm{ssrn}$. com/abstract_id $=1603484$.

108. Id. at 27.

109. Id.

110. See Stavros Panageas, The Neoclassical Theory of Investment in Speculative Markets 17 (Apr. 2005) (working paper), available at http://ssrn.com/abstract=720464 (discussing this proposition and implications for investment theory).

111. See José Scheinkman \& Wei Xiong, Overconfidence and Speculative Bubbles, 111 J. PoL. ECON. 1183, 1185-86 (2003).

112. See Patrick Bolton et al., Executive Compensation and Short-Termist Behavior in Speculative Markets, 73 REV. ECON. STUD. 577, 578-80 (2006) (“'S]tock prices may be higher than fundamental value when there are differences of opinion and short term constraints.").

113. Bratton \& Wachter, supra note 101, at 711. 
particularly institutional investors-are able to express their heterogeneous preferences by influencing corporate policies and decisions. The next Part discusses the effects of such influence. While shareholder influence may have beneficial effects, primarily through the reduction of agency costs, it also imposes costs on companies and shareholders that are not captured under the standard agency model, but can be explained and analyzed under a common agency model.

\section{GOVERNANCE IMPLICATIONS OF COMMON AGENCY}

Under agency theory, shareholder power and influence has been justified primarily as a means to reduce high agency costs imposed by shirking and rent-seeking managers. The literature analyzing this view is abundant and has provided theoretical support for the regulatory shift-primarily from the SEC-towards shareholder empowerment. However, existing regulations reflect both an overestimation of the benefits of shareholder empowerment and a simultaneous underestimation of the costs of shareholder empowerment where a common agency is present. A common agency has the potential to create a number of costs to both the corporation and to other shareholders:

1. More influential principals will attempt to persuade management to adopt policies and business decisions that are preferred by the influential shareholders but may not benefit all shareholders. Some of these policies and business decisions will provide private benefits to influential shareholders, and some decisions will result in the adoption of inefficient governance mechanisms.

2. Lobbying efforts by shareholders create costs for both the company and for the lobbying shareholders.

3 . Because of the potential costs of shareholder influence, crossshareholder monitoring and monitoring by any beneficiaries of influential investors become commensurately important.

The conception of the management-shareholder relationship as a common agency relationship allows shareholders to more fully appreciate and evaluate the costs and benefits of shareholder empowerment-the potential reduction of management agency costs on the one hand, and the potential creation of agency costs associated with common agency, including intrashareholder monitoring and bonding costs, on the other. This Part first discusses the growing literature on shareholder influence as a means to reduce agency costs caused by managerial expropriation, and then turns to the costs created by a common agency relationship. 


\section{A. Shareholder Activism and Corporate Performance: A Review of the Literature}

Scholars have given significant attention to the question of whether increased shareholder activism provides benefits to the corporation. ${ }^{114}$ Much of the literature in the last several years has been devoted to the question of whether hedge fund activism improves firm performance. Hedge fund activism arguably provides the best case for evaluating the benefits of shareholder activism. Yermack noted that "hedge funds have a number of intrinsic advantages as activists when compared to pension funds, mutual funds, or other institutional investors." 115 In particular, hedge funds have no diversification requirement, as do many other institutional investors, allowing hedge funds to concentrate efforts on a few target companies. Since their investors' capital is subject to lock-in requirements, hedge funds also have greater flexibility in selecting from a broader range of investments, including relatively less liquid securities. Hedge funds can operate with greater secrecy because they are subject to less comprehensive disclosure requirements than other institutions and may build up positions using trading strategies (such as empty voting) that are not permitted to mutual funds and pension funds. ${ }^{116}$ Taken together, Yermack concluded that these factors suggest that the costs of activism may be lower for hedge funds than for other institutions, and hedge funds may provide more opportunities for activism. ${ }^{117}$

114. The connection between various "good" corporate governance structures and firm performance (the existence of which would help justify much shareholder activism) remains a subject of considerable academic debate. A trading strategy based on an index of twenty-four governance provisions-Gompers, Ishii, and Metrick's "G-index"-would have earned higher than normal returns during the 1990s. Paul Gompers, Joy Ishii \& Andrew Metrick, Corporate Governance and Equity Prices, 118 Q. J. ECON. 107, 107 (2003). However, as shown by Bebchuk, Cohen and Wang, this correlation disappeared during the next decade. Lucian A. Bebchuk, Alma Cohen \& Charles C.Y. Wang, Learning and the Disappearing Association Between Governance and Returns 2-4 (Harvard Law \& Econ., Discussion Paper No. 667, 2010), available at http://ssrn.com/abstract=1589731. They explained this disappearance by arguing that market has learned to appreciate the value of strong governance in firms, noting the media coverage that corporate governance garnered throughout the 2000 s and concluded that the differences in governance are now built into share price. Id. Other explanations for this phenomenon have been given as well. See Andy Fodor \& Dean Diavatopoulos, Does Corporate Governance Matter for Equity Returns? 17 (Feb. 2, 2010) (working paper), available at http://ssrn.com/abstract=1546645 (explaining the previous findings by noting that most firms which were considered strong governance firms in the 1990s were tech firms, affected by the technology bubble that was not replicated in the 2000s). See also The Rewards of Virtue, ECONOMIST, Apr. 26, 2010 (discussing these previous studies and the issue of corporate regulation).

115. Yermack, supra note 74, at 26.

116. Id.

117. Id. 
John Armour and Brian Cheffins also examined the market conditions that allow hedge funds to become powerful shareholder activists. ${ }^{118}$ They explained that recent deregulation of investor eligibility requirements and reduction of financing limitations, ${ }^{119}$ as well as historically lower borrowing costs, ${ }^{120}$ allowed hedge funds to economically fund stock purchases, while new technological improvements allow hedge funds to easily target underperforming corporations and reduce other costs inherent to activism. ${ }^{121}$ For example, e-mail and websites now can be used to "fight public campaigns against incumbent managers." 122 Armour and Cheffins believe that these conditions allowed hedge fund activism to reach its prime early in the first decade of the twenty-first century and that the market environment generally will continue to be conducive to activism into the future. ${ }^{123}$

The relevant literature provides a mixed view of the value of hedge fund activism, although overall hedge fund activism appears to positively impact portfolio companies. Studies by Mary Bange and Werner De Bondt, as well as April Klein and Emanuel Zur, suggest that successful hedge fund activism does not reduce research and development investment, ${ }^{124}$ leading to a possible conclusion that hedge funds may not harm companies in the long-term by attempting to generate short-term gains. Alon Brav, Wei Jiang, Frank Portnoy, and Randall Thomas have shown that hedge fund investment and activism generate stock price gains that do not reverse in the subsequent year, and they also found that return on assets and return on sales of target companies improve for two years after the investment.125 Nicole Boyson and Robert Mooradian have shown that gains from hedge fund activism typically result from "aggressive" activism: obtaining a significant share of the target's stock, obtaining board control, and

118. John Armour \& Brian Cheffins, The Rise and Fall (?) of Shareholder Activism by Hedge Funds 1 (Eur. Corporate Governance Inst., Law Working Paper No. 136, 2009), available at http://papers.ssrn.com/sol3/papers.cfm?abstract_id=1489336.

119. Id. at 27.

120. Id. at $27-28$.

121. Id. at 15 .

122. Id.

123. Id. at 30 .

124. Mary M. Bange \& Werner F.M. De Bondt, R\&D Budgets and Corporate Earnings Targets, 4 J. CoRP. FIN. 153, 154 (1998); April Klein \& Emanuel Zur, Hedge Fund Activism 32 (Eur. Corporate Governance Inst., Finance Working Paper, No. 140, 2006), available at w4.stern.nyu.edu/clb/docs/06-017.pdf.

125. Alon Brav et al., The Returns to Hedge Fund Activism 2, 12 (Eur. Corporate Governance Inst., Law Working Paper No. 098, 2009), available at http://ssrn.com/abstract=1111778. 
obtaining a variety of securities from the target, among other factors. ${ }^{126}$ Less intense activism does not produce positive returns. ${ }^{127}$

Other results are more ambivalent. A later study by Robin Greenwood and Michael Schor suggests that "activist funds are like a boxer with one punch: They are most successful when they prod managers to put a company up for sale."128 However, when the target company is not sold, activist investors are much less successful: "In those cases, the study found there is little change in the next 18 months in the company's stock price or financial results. That is true even when the company takes steps recommended by the activists, such as firing the chief executive, buying back stock or adding new directors."129

Public pension funds are also influential activists, although their influence seems to produce less of an impact than hedge fund activism. Yermack provides a review of pension fund activism, ${ }^{130}$ citing studies by Sunil Wahal, ${ }^{131}$ Carleton, Nelson and Weisbach, ${ }^{132}$ and Yonca Ertimur, Fabrizio Ferri and Stephen Stubben ${ }^{133}$ that find some evidence of effectiveness of public pension fund activism in spurring changes in corporate policy. An extensive literature review by Jonathan Karpoff, ${ }^{134}$ on the other hand, analyzes over twenty studies conducted on the impact of activism and finds that activism has "negligible impacts on share values and earnings." 135 Likewise, after reviewing the considerable literature on the effect of shareholder proposals on firm value, Stuart Gillan and Laura Starks found little long-term positive effect: The evidence provided by empirical studies of the effects of shareholder activism is mixed. While some studies have found positive short-term market reactions to announcements of

126. Nicole M. Boyson \& Robert M. Mooradian, Hedge Funds as Shareholder Activists from 1994-2005, at 2-4 (July 31, 2007) (unpublished manuscript), available at http://ssrn.com/abstract=992739.

127. Id. at 20 .

128. Scott Thurm, When Investor Activism Doesn't Pay, WALL ST. J., Sept. 12, 2007, at A2 (discussing the study by Robin Greenwood and Michael Schor).

129. Id.

130. Yermack, supra note 74 , at 24-25.

131. Sunil Wahal, Pension Fund Activism and Firm Performance, 31 J. Fin. \& QUANTITATIVE ANALYSIS 1, 4 (1996).

132. Carleton et al., supra note 55, at 1335-37.

133. Yonca Ertimur, Fabrizio Ferri \& Stephen R. Stubben, Board of Directors Responsiveness to Shareholders: Evidence from Shareholder Proposals, 16 J. CoRP. FIN. 53, 69 (2010).

134. Jonathan M. Karpoff, The Impact of Shareholder Activism on Target Companies: $A$ Survey of Empirical Findings 28 (Aug. 18, 2001) (working paper), available at http://ssrn.com/abstract $=885365$.

135. Id. 
certain kinds of activism, there is little evidence of improvement in the long-term operating or stock-market performance of the targeted companies. ${ }^{136}$

As described in Part II.B, many activist shareholders do not always pursue their objectives publicly, making it relatively more difficult to evaluate the agency costs associated with their influence. Some shareholders will first try to engage management in discussions before or after initiating their proposal, often in the hope that management will ultimately agree to put forward the proposal as its own. This hidden influence presents potential benefits for both the company and the activist. First, the shareholder activist has a much greater likelihood of succeeding in its objective if it is able to withdraw its proposal and negotiate with the company to recast it as a management proposal. Management proposals have a much greater likelihood of success primarily because passive shareholders such as mutual funds tend to vote in lockstep with management's proposals. The company benefits because it is able to avoid a contentious fight with respect to a corporate governance issue, present itself as taking the high road, and demonstrate engagement with shareholders.

Empirically, however, there is little support for the value of such behind-the-scenes shareholder influence; the existing data suggest that companies are likely agreeing to governance policies that are weakly or not at all tied to firm performance. The major study on the effects of withdrawn proposals supports this conclusion. N.K. Chidambaran and Tracie Woidtke examined shareholder proposals withdrawn during the period of 1989 to 1995 to examine the valuation effects associated with withdrawn proposals. ${ }^{137}$ The authors compared the three-year period prior to the SEC's 1992 proxy rule changes to the three-year period following the changes. The 1992 proxy changes provided for liberalized information flow about proxy proposals and allowed for greater coordination among investors, which should, by design, allow for greater shareholder influence and increase shareholders' negotiating power with management. The authors found that prior to the 1992 reforms, withdrawals were associated with a positive valuation effect, while withdrawals after the reforms were associated with a negative valuation effect. ${ }^{138}$ The authors surmise that because of the increased negotiating power of activist

136. Stuart Gillan \& Laura Starks, The Evolution of Shareholder Activism in the United States, J. APPLIED CORP. FIN., Winter 2007, at 69.

137. N.K. Chidambaran \& Tracie Woidtke, The Role of Negotiations in Corporate Governance: Evidence From Withdrawn Shareholder-Initiated Proposals 17 (N.Y. Univ. Ctr. for Law \& Business, Research Paper No. 99-12, 1999), available at http://ssrn.com/abstract=209808.

138. Id. at 2-3. 
shareholders, shareholders were increasingly able to successfully promote corporate governance proposals. ${ }^{139}$ However, on the whole, these governance changes did not improve corporate performance. ${ }^{140}$ The authors noted that this result is "consistent with the notion that some shareholders may be driven by special interests in suggesting policy changes that are not necessarily value increasing." 141

Overall, numerous studies and reviews suggest that shareholder influence is limited in its ability to improve corporate performance. However, because the studies typically review effects across a wide range of companies, it is likely the case that welltargeted activism is a useful tool in reducing high agency costs. Nevertheless, some studies also suggest that the goals of reducing agency costs and maximizing pro rata shareholder returns are not an adequate explanation for all shareholder activism. If that were the case, we could assume that some activist shareholders systematically and irrationally waste their efforts on activism that has little impact on the value of their investment. While this may be true in some cases (e.g., some shareholders mistakenly but in good faith attribute value to ineffective or inapt corporate governance policies), the following section considers an alternative explanation for shareholder efforts to influence corporate policy and decisionmaking.

\section{B. Private Benefits from Shareholder Activism}

There are numerous explanations for shareholder efforts to exert influence over the board and management, but they generally fall under two basic, nonexclusive categories. The first explanation, discussed above, is that the shareholders simply seek to reduce agency costs-shareholders use their influence as a check on the power of the board and management to minimize management shirking and to limit the private benefits that managers may extract at the expense of shareholders.

The second, less benign, explanation is that shareholders seek to influence the corporation in order to extract private benefits that do not inure to other shareholders. The goal of this influence is not always a direct pecuniary benefit, but may be to obtain benefits for a constituency, achieve political goals, or effect social change (what

139. Id. at 3 .

140. Id.

141. Id. at 17 . 
Joseph Grundfest has labeled "megaphone externalities"142). Regardless of the shareholders' motivations, common agency theory suggests that the ability of shareholders to influence managerial decisionmaking to extract private benefits should have an effect on overall agency costs. Consistent with this explanation, Craig Depken, Giao Nguyen, and Salil Sarkar found that a higher percentage of blockholder ownership (a reasonable proxy for ownership by influential investors) is positively related with agency costs, which they interpret as evidence of the private benefit hypothesis. ${ }^{143}$

Some commentators have argued that hedge funds occasionally seek to influence managers to promote the funds' interests at the expense of other investors. ${ }^{144}$ Hedge funds may also engage in "empty voting" or other trading practices that decouple their economic interest in a firm from their voting rights. ${ }^{145}$ Critics have noted that hedge funds often have short investment horizons, which may conflict with the objectives of long-term investors. ${ }^{146}$ Iman Anabtawi, for example, argued that in order to effectively compete for capital, some hedge funds favor policies that produce short-term gains "even if a more patient investment orientation would generate higher returns over the long term." 147 She contrasted this approach with the orientation of pension fund or life insurance companies, which are more likely to be concerned about the long-term value because of the need to meet future obligations. ${ }^{148}$

142. Joseph Grundfest, The SEC's Proposed Proxy Access Rules: Politics, Economics, and the Law, 65 Bus. LAW, 361, 365 (2010).

143. Craig A. Depken, Giao X. Nguyen \& Salil K. Sarkar, Agency Costs, Executive Compensation, Bonding and Monitoring: A Stochastic Frontier Approach 4 (2009), available at http://www.belkcollege.uncc.edu/cdepken/P/agencycosts.pdf. Depken, Nguyen, and Sarkar note the tension inherent in shareholder influence:

On one hand, blockholders have the incentive to act as monitors of the firm and to improve management, with the benefits shared with other shareholders. On the other hand, blockholders can also have private incentives to consume corporate resources or to otherwise go along with managerial decisions that might be deleterious to firm performance.

Id. at 3 .

144. See, e.g., Iman Anabtawi \& Lynn Stout, Fiduciary Duties for Activist Shareholders, 60 STAN. L. REV. 1255, 1260 (2008) (noting that activist shareholders may pressure corporate officers to pursue business opportunities that are beneficial to the activist); Iman Anabtawi, Some Skepticism About Increasing Shareholder Power, 53 UCLA L. REV. 561, 562-65 (2006) (discussing the debate over how to apportion corporate decisionmaking).

145. Henry T.C. Hu \& Bernard S. Black, The New Vote Buying: Empty Voting and Hidden (Morphable) Ownership, 79 S. CAL. L. REV. 811, 815 (2006).

146. Anabtawi, Some Skepticism About Increasing Shareholder Power, supra note 144, at 579 .

147. Id. at 564 .

148. Id. 
Investors may also obtain private benefits by advocating for corporate governance changes that align with their social preferences (a particular conception of good corporate citizenship, for example) or further a goal not directly related to the portfolio company's performance. Some labor unions, for example, show a tendency to vote against a portfolio company's director nominees when the portfolio company is experiencing labor strife. ${ }^{149}$ These types of private benefits are more likely to be sought when the investor is weakly incentivized to pursue higher share prices as a primary goal, such as when the compensation of the fund manager is not directly tied to the performance of the fund, or when the investor is operating under an investment mandate that requires or encourages the investor to invest within certain social or ethical constraints.

Even when the shareholder is not seeking immediate private gains, a common agency perspective of shareholder activism suggests that influential shareholders will still tend to push for changes in the allocation of corporate power to facilitate the future extraction of private benefits. This may explain the efforts of both professional corporate governance advisors and their main constituency, influential institutional investors, to perpetuate a shareholder engagement model maximizing their influence in corporate governance matters, even in cases where it is unclear whether the governance changes they support will beneficially affect corporate performance. ${ }^{150}$

This analysis is not intended to suggest that for every corporation the private benefit costs associated with influential shareholder activity will inevitably result in a net detriment to the corporation. With poorly managed firms in particular, higher shareholder involvement may be beneficial to the firm, even if the exercise of that influence provides a private benefit to a shareholder. For example, an influential shareholder could propose curbs on executive pay solely because the investor desires to encourage social equity. Such a change may simultaneously reduce managerial expropriation and yet also provide private benefits. So long as the

149. See Ashwini K. Agrawal, Corporate Governance Objectives of Labor Union Shareholders 1 (Stern Working Paper Series, No. Fin-08-006, 2008), available at http://papers.ssrn.com/sol3/papers.cfm?abstract_id=1285084. Agrawal studied the proxy votes of the AFL-CIO pension funds, noting that the AFL-CIO became significantly more supportive of firms' directors in organizations where the employees changed affiliation from the AFL-CIO to a different organization, a trait not evident in mutual funds and other labor union shareholders, thus indicating that labor relations affect the voting patterns of some union shareholders. He also found that when there was labor strife at a AFI-CIO affiliated company, the AFI-CIO was more likely to vote against the directors; however this correlation disappeared when the employees disaffiliated with the AFI-CIO. Id.

150. See supra notes 144, 149. 
reduction in managerial expropriation exceeds the private benefits to the influential shareholder, other shareholders should not be opposed to such private benefits ${ }^{151}$-effectively, the other shareholders would be willing to pay a corporate governance bounty. Yet shareholder influence can be harmful to the majority of shareholders if powerful shareholders and managers are able to trade votes in director elections for the shareholders' preferred governance changes. This kind of benefit exchange has two detrimental effects: it further entrenches directors and management who are friendly to a particular shareholder, and it creates governance systems that are suboptimal.

\section{Other Common Agency Costs}

Evidence of shareholder behavior suggests that some shareholders extract private benefits from corporations. However, even if we assume that most influential shareholders are not seeking private benefits through activism, viewing shareholder activism through the lens of common agency theory reveals other costs that are not apparent through standard agency theory. These costs are not accounted for because the federal regulatory framework currently relies on standard agency theory. This Section outlines a number of potential costs that common agency relationships create within public corporations.

\section{Lobbying Costs}

A common agency model of the corporation assumes that managers will owe fiduciary duties to all shareholders and that the managers will attempt to satisfy the preferences of shareholders consistent with these duties. Assuming under our common agency model that shareholders are both influential and have heterogeneous preferences, shareholders will lobby companies in order to influence the selection of the shareholders' governance preference. These lobbying efforts create costs for shareholders. Suppose that two shareholders are attempting to influence a corporation to adopt a particular governance policy. Unlike the standard (collective) corporate agency model under which shareholders possess similar governance preferences, both shareholders will expend resources in attempting to convince managers to adopt their preferences while perhaps also arguing against the preferences of other shareholders. Even if the corporation ultimately fails to adopt either investor's 
preference, the corporation and both investors will have costs associated with this lobbying activity. Anabtawi labeled the costs borne by such investors as "squabbling costs."152 Although conflicting shareholders are the only ones who bear these squabbling costs, "squabbling consumes resources that have a positive opportunity cost elsewhere in the economy simply by attempting to shuffle wealth among shareholders. Thus, even assuming that squabbling does not affect firm value, it reduces the welfare of the shareholders involved." 153

\title{
2. Efficiency Costs
}

Corporate responses to shareholder influence may also have two detrimental effects on governance efficiency. First, by reallocating power within a corporation, the corporation may become less efficient in its decisionmaking. As Stephen Bainbridge has argued, allowing shareholders to exert authority or excessive influence over directors reduces the efficiency of a director-centric model of governance. ${ }^{154}$ Shareholder influence over corporate decisionmaking

\begin{abstract}
seems likely to disrupt the very mechanism that makes the public corporation practicable; namely, the centralization of essentially non-reviewable decision-making authority in the board of directors... Under conditions of widely dispersed information and the need for speed in decisions, authoritative control at the tactical level is essential for success. ${ }^{155}$
\end{abstract}

Second, increasing shareholder power may also result in specific, suboptimal changes to the governance structure of the corporation even if no private benefits are granted or exchanged. Suppose that a shareholder has successfully influenced a corporation to adopt a particular policy. While the investor's preferred policy may result in reduced agency costs, the benefits of the policy change must still be weighed against the long-term costs of the policy change. The newly proposed say-on-pay rules, which are substantially the result of regulatory lobbying by institutional investors, are a clear example of how empowering investors to reduce agency costs may create other governance complications, including homogenized governance structures. Considering the effectiveness of the UK's say-on-pay rules, Jeffrey Gordon has observed:

152. Anabtawi, Some Skepticism About Increasing Shareholder Power, supra note 144, at 577.

153. $I d$.

154. Stephen Bainbridge, Director Primacy and Shareholder Disempowerment, 119 HARV. L. REV. 1735 (2006).

155. Id. at 1749 (quoting KENNETH ARROW, THE LIMITS OF ORGANIZATION 69 (1974)). 
If the goal is to devise a compensation system that will better link pay and performance, mandatory "say on pay" as currently proposed is a dubious choice. Based on the UK experience, a comparable US regime is likely to lead to a narrow range of approaches to the inherently difficult problem of executive compensation that will then be adopted across the 10,000 U.S. firms that are likely to be covered. This narrow range, close to a "one size fits all," is highly likely because the burden of annual voting would lead investors, particularly institutional investors, to farm out evaluation of most pay plans to a handful of proxy advisory firms who themselves will seek to economize on proxy review costs. Custom-tailored evaluation is costly; monitoring for adherence to "guidelines" or "best practices" is cheap. Given our recent experience with stock options, which were vigorously promoted by institutional investors in the $1990 \mathrm{~s}$ as a shareholder-alignment mechanism, we would be well to avoid another rush to economywide adoption of a particular normative conception of executive compensation. ${ }^{156}$

Steen Thomsen made a similar argument with respect to influential codes of best practices for corporations, on which many powerful shareholders rely, in order to encourage governance changes at public corporations. ${ }^{157}$ The costs of monitoring could partially explain why institutional investors and proxy advisors advocate for one-size-fits-all governance policies. Institutional investors may more easily monitor compliance with a specific governance ideal, even if it may not be appropriate for a particular company. Thomsen also argues that the institutional investors' promotion of common global corporate governance standards may also be explained by the fact that, while firms are very different, "institutional investors across the world are relatively similar. They provide the same standard commodity to their customers using more or less the same financial techniques, in particular portfolio diversification." 158 Competition for investment by such funds may compel companies to accept inapt governance structures.

156. Jeffrey Gordon, "Say on Pay": Cautionary Notes on the U.K. Experience and the Case for Shareholder Opt-In, 46 HARV. J. ON LEGIS. 323, 325-36 (2009). Gordon's observation is supported by research from Cai and Walkling:

Congress and activists recently proposed giving shareholders a say (vote) on executive pay. We find that when the House passed the Say-on-Pay Bill, the market reaction was significantly positive for firms with high abnormal CEO compensation, with low pay-for-performance sensitivity, and responsive to shareholder pressure. However, activist sponsored say-on-pay proposals target large firms, not those with excessive CEO pay, poor governance, or poor performance. The market reacts negatively to labor sponsored proposal announcements and positively when these proposals are defeated. Our findings suggest that say-on-pay creates value for companies with inefficient compensation, but can destroy value for others.

Jay Cai \& Ralph A. Walkling, Shareholders' Say on Pay: Does It Create Value?, J. Fin. \& QUANTITATIVE ANALYSIS (forthcoming) (manuscript at 1), available at http://ssrn.com/abstract= 1030925.

157. Steen Thomsen, The Hidden Meaning of Codes: Corporate Governance and Investor Rent Seeking, 7 EUR. BUS. ORG. L. REV. 845 (2006).

158. Id. at 850 . 
As with lobbying efforts, inefficient structures and governance policies may not be direct common agency costs. Nonetheless, these policies may result in a loss of value for the company due to pressures from shareholders, just as a transaction would in which a shareholder influences a company to provide it with a special benefit. From an economic perspective, a change that creates an inefficient structure in order to appease a shareholder and avoid a proxy battle produces a cost to the company just as would an outright payment to the shareholder. As an empirical matter, it is not clear whether the corporate governance initiatives that proxy advisors and activist shareholders promote ultimately enhance the value of the corporation. ${ }^{159}$ A call for adherence to "best practices" in corporate governance often just means the application of an undifferentiated model of governance to a particular corporation, without regard to any factors other than the company's relatively poor position on a given corporate governance rating index. ${ }^{160}$

159. Sanjai Bhagat, Brian Bolton, \& Roberta Romano, The Promise and Peril of Corporate Governance Indices, 108 COLUM. L. REV. 1803, 1803-04 (2008).

160. In their recent study Bhagat, Bolton and Romano conclude:

[T] here is no consistent relation between governance indices and measures of corporate performance. Namely, there is no one "best" measure of corporate governance: The most effective governance system depends on context and on firms' specific circumstances. It would therefore be difficult for an index, or any one variable, to capture nuances critical for making informed decisions. As a consequence, we conclude that governance indices are highly imperfect instruments for determining how to vote corporate proxies, let alone for making portfolio investment decisions, and that investors and policymakers should exercise caution in attempting to draw inferences regarding a firm's quality or future stock market performance from its ranking on any particular corporate governance measure.

Id. at 1803. Daines, Gow, and Larckner also report that the governance ratings offered by RiskMetrics, The Corporate Library, and GMI "have either limited or no success in predicting firm performance or other outcomes of interest to shareholders." Robert Daines, Ian D. Gow \& David F. Larcker, Rating the Ratings: How Good are Commercial Governance Ratings? 46 (Stan. L. and Econ. Olin, Working Paper No. 360; Stan. Univ. Rock Ctr. for Corp. Governance, Working Paper No. 1, 2009), available at http://ssrn.com/abstract=1152093. They note, however, that despite their deficiencies, governance ratings still significantly affect the decisionmaking of shareholders, directors and managers:

These ratings also change firm practices when boards seek to increase their ratings. Aetna and GE reportedly hired ISS to recommend governance changes that would boost their ratings; the implemented changes lifted their ratings from ten percent to more than ninety percent. Do such ratings-driven changes lead to better outcomes? The question is broader than the hundreds of similar firms that pay for advice on what they should change. In a recent survey, public firm directors listed corporate governance advisors as the third most influential institution on board, behind only institutional investors and analysts, and ahead of activist hedge funds or shareholder plaintiffs. Directors also said that a low governance rating is an important red flag that prompts them to increase their monitoring .. falling just behind the firm's missing analysts' earnings estimates in importance.

Id. at 2. 
As Bratton and Wacher described, costs to the corporation could also result from adoption of corporate policies based on heterogeneous investor expectations. ${ }^{161}$ Using heterogeneous expectations models, the authors summarize three potential corporate governance implications: first, the market price may no longer represent the views of the shareholders as a whole or even a majority of the shareholders; second, the market price may not represent the pro rata value of the corporation; and third, mispricing is likely to affect investment behavior within the corporation, and this investment behavior may be to the detriment of the corporation. ${ }^{162}$ Consistent with a common agency model, in which managers attempt to meet their fiduciary duties to both influential institutional investors and also more passive blockholders or retail investors with smaller positions, Bratton and Wachter noted that adopting an agency view of the corporation encourages managing to the market. Here, managers are more likely to pursue a riskier proposition that favors the interests and expectations of the more optimistic shareholder. ${ }^{163}$

Finally, business strategies can also be adversely affected by heterogeneous investor expectations. Falaschetti argued that dissimilar motivations for different shareholder groups can cause infighting, and thus instability within the firm. ${ }^{164} \mathrm{He}$ asserted that corporations benefit from a concentration of decisionmaking authority ${ }^{165}$ and presents evidence that that increased shareholder power actually causes managers and bondholders to bargain for

161. Bratton \& Wacher, supra note 101, at 706.

162. Id.

163. Bratton and Wachter's work argues in support of the prevailing legal model (under state corporate law) that protects directors through the business judgment rule, which would allow them to ignore the preferences of an influential investor if it conflicts with the preferences of other investors. This Article, by contrast, takes shareholder power as a given; shareholder power is unlikely to decrease, and likely to increase. Rather than explicitly arguing against shareholder power, this Article instead seeks to illuminate the costs of shareholder power, assuming the current regulatory trajectory continues.

164. Dino Falaschetti, Shareholder Democracy and Corporate Governance 8 (Fla. St. U. Coll. of Law, Public Law Research Paper No. 333, 2008) available at http://ssrn.com/abstract= 1312447.

165. Id. Falaschetti uses the example of a mining company considering whether to expand by using either a labor or capital basis, or simply keeping the status quo. He supposes that using the capital basis will create more profits and cause less environmental damage than the labor option, while the labor option will create the most environmental damage and less profits. "Profit maximizing" shareholders would likely support the capital option first and the labor option second, rather than keeping the status quo. However, a labor union shareholder might prefer increasing employment over keeping the status quo, and the status quo over the employmentreducing capital option. Finally, shareholder groups more interested in social issues would likely most prefer the status quo, followed by capital expansion. In this situation, infighting could ensue, preventing the adoption of any strategy and thus harming all shareholders. 
additional safeguards, such as golden parachutes and increased bond rates, in return for exposing themselves to increased risks from shareholder power. ${ }^{166}$

The evidence of shareholder influence presented in this Article suggests that concern over heterogeneity of investor preferences is not a mere academic curiosity. Shareholder primacy is, for practical purposes, already entrenched in federal law, and shareholder power increasingly affects corporate decisionmaking. Corporate managers must manage a common agency relationship that results in competing influences over their decisionmaking.

\section{Cross-Shareholder Monitoring and Shareholder Bonding Costs}

Thus far this Article has identified two types of agency costs associated with common agency. First, agency costs arise when shareholders affect decisionmaking and result in residual losses through a payment of private benefits to the shareholders. Agency costs may also occur from adopting inefficient governance structures, even if the adoption of such costs does not provide a private benefit to a particular shareholder. In addition, some minor but nevertheless non-negligible costs may also occur as a result of cross-shareholder monitoring-shareholders will monitor other shareholders in order to limit other shareholders' influence that is counter to their own interests. Monitoring is efficiently facilitated through required public disclosures, and disclosure costs are primarily borne by the corporation. As will be discussed in the following Section, however, current regulations do not produce adequate disclosure of common agency costs.

Because of the potential costs of shareholder influence, some shareholders also incur bonding costs by expressly agreeing to limit their activities. For instance, foreign investors (including sovereign wealth funds) routinely incur bonding costs when they purchase large blocks of shares in U.S. corporations. ${ }^{167}$ These investors provide a bond to other shareholders as a result of mitigation agreements with U.S. regulators or through securities purchase agreements with the corporation that, for example, limit the voting rights of the shareholder. ${ }^{168}$ Other investors may also have internal, institutional constraints that limit the scope of acceptable activism. For example,

166. Id. at 13-16.

167. See Paul Rose, Sovereigns as Shareholders, 87 N.C. L. REv. 83, 128 (2008) (citing the examples of Germany, France, and Russia).

168. Id. 
fund managers may have proxy voting policies that either dictate the institution's position on certain issues, such as executive compensation, or limit the ability of the institution to take positions on social responsibility issues. A fund's policy may also state that social policy matters relating to a company's day-to-day business operations "are primarily the responsibility of management," 169 and so the fund "will normally vote against shareholder proposals requesting that a company disclose or change certain business practices unless [the fund] believe[s] the proposal would have a substantial positive economic impact on the company."170

The preceding material has provided an overview of the costs created by common agency in public corporations. The following Part takes up the question of how these costs may be reduced through private and governmental regulatory efforts.

\section{REGULATORY IMPLICATIONS OF COMMON AGENCY: PRELIMINARY CONSIDERATIONS}

In analyzing shareholder activism under a common agency model, it is apparent that relying on a standard agency model, in which shareholders act as collective principals, creates significant regulatory gaps. This Article discusses how existing and currently proposed regulations fail to adequately respond to the particular problems that common agency creates. It will offer some preliminary thoughts on how regulators could respond to resolve some of these problems. In particular, this Part will discuss how agency costs in general may be reduced by the imposition of fiduciary duties and through enhanced disclosure requirements.

An understanding of the implications of common agency calls into question the SEC's commitment to shareholder primacy. The potential for deleterious shareholder influence is reduced through regulations that limit communications between shareholders, limit the types of matters on which shareholders can vote, limit the types of proposals that shareholders may sponsor, and impose fiduciary duties on certain investors, which in turn generally limits the ability of some institutional investors to engage in social activism. Yet, the SEC's increasing regulatory commitment to investor empowerment diminishes the moderating effects of these rules. Without limitations

169. See, e.g., OAKMARK Funds, Description of Proxy Voting Policies, Guidelines, AND PROCEDURES, available at http://www.oakmark.com/forms/pdf/proxypolicy.pdf.

170. Id. 
on the exercise of shareholder power, enhancing shareholder power is more likely to exacerbate agency costs than resolve them.

The overall effect of the SEC's recent and proposed proxy regulations is to further reallocate power between shareholders and managers. As regulated agents, managers become "more accountable" to shareholders. This accountability increases the influence of shareholders, but it is not clear that all shareholders will benefit. As the potential for higher costs associated with common agency increases, an initial solution is to roll back some of the gains in shareholder power. However, an attempt to reduce shareholder power is likely to meet strong resistance. An example of shareholders' resistance to limitations of their power-a private effort, rather than a regulatory change - is found with an unusual shareholder proposal from the 2008 proxy season. Steven Milloy171_an ExxonMobil shareholder, Fox News reporter, and shareholder activist-proposed that "the Company amend its bylaws to no longer permit shareholders to submit precatory (non-binding or advisory) proposals for consideration at annual shareholder meetings, unless the board of directors takes specific action to approve submission of such proposals."172 Like many of the shareholder proposals he argued against, Milloy's proposal was stillborn. ExxonMobil was sympathetic to the proposal, noting that "the Board does not believe the proxy statement is the most appropriate venue for many of the issues currently raised by shareholder proposals."173 However, the Board recommended against voting for the proposal, stating that it "does not believe the by-law amendment proposed by the proponent is the best way to carry out reform of the shareholder proposal process at this time." ${ }^{174}$ Milloy's proposal received less than three percent support in shareholder voting.

171. Milloy has actively campaigned against what he terms "junk science." "Junk science" is defined as "faulty scientific data and analysis used to advance special and, often, hidden agendas." Junk Science?, JUNKSCIENCE.COM, http://junkscience.com/define.html (last visited Aug. 10, 2010).

172. ExxonMobil Corp., Definitive Proxy Statement (Schedule 14A) 49 (Apr. 10, 2008), available at http://www.sec.gov/Archives/edgar/data/34088/000119312508078618/ddef14a.htm. In his supporting statement, Milloy argued that stock ownership has "become politicized," and that many shareholders own stock solely to use the proxy process as "a means of advancing the particular shareholders' social or political agenda." Id. He also argued that through the proposals activist shareholders could increase their "pressure and influence over corporate governance, executive compensation, corporate political contributions, employment policy, and environmental practices." Id.

173. Id.

174. Id. 
Reducing shareholder power is unpopular with most active shareholders for obvious reasons. If attempted in a piecemeal fashion, as with ExxonMobil, it is likely to be unpopular with management who do not want to appear to be adversarial to shareholders. ${ }^{175}$ Efforts to privately limit shareholder power within the corporate structure must also swim against the tide of regulation. It is difficult to imagine a broad reform of shareholder power that would result in shareholders holding less power. A prudent response to potential common agency costs would be to evaluate how shareholders have used their increased power before determining to give them more power.

Regardless of whether shareholders gain more relative power through additional federal corporate governance regulation, two primary regulatory mechanisms that have been used to limit agency costs-the imposition of fiduciary duties and disclosure requirements-may also serve to reduce some of the costs associated with common agency. There are, however, considerable complexities involved in the regulation of shareholder behavior. Thus, the reduction of common agency costs through additional regulation is likely to be a more complicated challenge than regulating managerial expropriation.

\section{A. Regulating Agency Costs Through Fiduciary Duties}

Fiduciary duties reduce agency costs by imposing limits on an agent's ability to act in his or her own interest at the expense of the party to whom the duties are owed. Traditionally, fiduciary duties in the corporate context are owed by managers (which include directors and, generally speaking, officers) to shareholders. Fiduciary duties also arise between investors and money managers. The fiduciary responsibility owed to shareholders in both cases could carry a greater burden in reducing agency costs arising from shareholder influence. Further, some scholars have suggested that the application of fiduciary duties to activist minority shareholders could provide a more direct check on detrimental shareholder influence.

175. It is possible that some companies would adopt such a bylaw if they were regular targets of social or other non-wealth-focused activists. However, it is telling that ExxonMobil, which has such shareholders in abundance, did not sponsor Milloy's proposal (which in any event probably would not have received many votes even if sponsored by management). Under the current regulatory environment, responsiveness to shareholder concerns is paramount. 


\section{Fiduciary Duties Owed by Fund Managers to Investors}

Fiduciary duties are especially important where market forces cannot exert a disciplining effect, such as in the case with pension funds where the investors' capital is locked in. Federal laws governing pension funds, which often engage in activism, also limit the ability of such funds to engage in benefit-seeking at the expense of other shareholders. Because of the increased activism of many funds, the Department of Labor under the Bush Administration reiterated the importance of investing and voting on economic grounds. ${ }^{176}$ With respect to proxy voting, the Department stated that fiduciaries shall "consider only those factors that relate to the economic value of the plan's investment and shall not subordinate the interests of the participants and beneficiaries in their retirement income to unrelated objectives."177 Further, the fund has an obligation to refrain from voting proxies if it determines the cost of voting, including the cost of research on the proxy issues, is likely to exceed the expected economic benefits of voting. ${ }^{178}$

The Department of Labor has focused on issues that generally relate to the reduction of management agency costs, such as director independence, director nominee expertise, executive compensation, antitakeover protections, the extent of debt financing and capitalization, long-term business plans, and workplace practices that are tied to economic value. ${ }^{179}$ Pointedly, the Department of Labor stated that "a fiduciary... shall not use an investment policy to promote myriad public policy preferences." 180

176. This position was first set out in the Department of Labor's now-famous "Avon Letter." See Letter from the Dep't of Labor to Helmuth Fandl, Chairman of Retirement Bd., Avon Prods., Inc. (Feb. 23, 1988), reprinted in 15 Pens. \& Ben. Rep. (BNA) 391 (Feb. 29, 1988).

177. 73 Fed. Reg. 61,731, 61,732 (Oct. 17, 2008).

178. See Dep't of Labor Advisory Opinion No. 2007-07A, Pens. Plan Guide (CCH) P 19,991Z, 2007 WL 4616370 (Dec. 21, 2007). With respect to the exercise of shareholder influence generally, the Department of Labor has also stated:

An investment policy that contemplates activities intended to monitor or influence the management of corporations in which the plan owns stock is consistent with a fiduciary's obligations under ERISA where the responsible fiduciary concludes that there is a reasonable expectation that such monitoring or communication with management, by the plan alone or together with other shareholders, will enhance the economic value of the plan's investment in the corporation, after taking into account the costs involved.

73 Fed. Reg. at 61,734 .

179. 73 Fed. Reg. at 61,734 .

180. Id. (citing Dep't of Labor Advisory Opinion No. 2008-05A, Pens. Plan Guide (CCH) P 19,992D, 2008 WL 2702194 (June 27, 2008), and Letter from Dep't of Labor to Jonathan P. Hiatt, Gen. Counsel, AFL-CIO (May 3, 2005)). With respect to social activism particularly, the Department of Labor warned plan fiduciaries of the enforcement risk created by such activism: 
Like the Department of Labor, the SEC has also promulgated regulations applying fiduciary duties to investment advisers with respect to proxy voting. Registered investment advisers collectively have the discretionary authority to manage trillions of dollars in assets, including very large equity positions, and " $[t]$ his enormous voting power gives advisers significant ability collectively, and in many cases individually, to affect the outcome of shareholder votes and influence the governance of corporations." 181 While the Investment Advisers Act of 1940 does not define the contours of these fiduciary duties, the SEC believes the duty of care requires the adviser "to monitor corporate events and to vote the proxies"182 and that the duty of loyalty requires the adviser to "cast the proxy votes in a manner consistent with the best interest of its client and [to] not subrogate client interests to its own." 183 The SEC mentions two readily apparent conflicts that may affect an adviser's duty of loyalty. First, an adviser may manage a pension plan or provide other services to a company whose management is soliciting proxies. ${ }^{184} \mathrm{~A}$ failure to vote in favor of the management's slate and proposals may damage the adviser's business relationship with the company. Second, "[t]he adviser may have business or personal relationships with participants in proxy contests, corporate directors or candidates for directorships." 185 For instance, an executive of the adviser may have a spouse serving as a board member at the company. The SEC's rules are designed to protect against such conflicts by requiring advisers "to adopt and implement policies and procedures for voting proxies in the best interest of clients, to describe the procedures to clients, and to tell

Plan fiduciaries risk violating the exclusive purpose rule when they exercise their fiduciary authority in an attempt to further legislative, regulatory or public policy issues through the proxy process. In such cases, the Department would expect fiduciaries to be able to demonstrate in enforcement actions their compliance with the requirements of section $404(\mathrm{a})(1)(\mathrm{A})$ and (B). . . . Because of the heightened potential for abuse in such cases, the fiduciaries must be prepared to articulate a clear basis for concluding that the proxy vote, the investment policy, or the activity intended to monitor or influence the management of the corporation is more likely than not to enhance the economic value of the plan's investment before expending plan assets. The use of pension plan assets by plan fiduciaries to further policy or political issues through proxy resolutions that have no connection to enhancing the economic value of the plan's investment in a corporation would, in the view of the Department, violate the prudence and exclusive purpose requirements of section 404(a)(1)(A) and (B).

Id.

181. In re Proxy Voting By Investment Advisors, Investment Advisors Act of 1940 Release No. IA-2106, 79 SEC Docket 1673, 2003 WL 215467, at *2 (Jan. 31, 2003).

182. $I d$.

183. $I d$.

184. Id.

185. Id. 
clients how they may obtain information about how the adviser has actually voted their proxies." 186

As with the Department of Labor rules, the SEC suggests that in some cases, an adviser may have a duty to avoid voting proxies if he or she determines that the cost of voting the proxy exceeds the expected benefit to the client. ${ }^{187}$ However, an adviser may not "ignore or be negligent in fulfilling the obligation it has assumed to vote client proxies." 188

Despite the voting power of active institutional investors, the SEC has given relatively little attention to enforcement of the fiduciary duties created by its proxy voting rules. However, in an important 2009 civil proceeding, the SEC settled with an investment adviser in an action alleging a violation of these duties. ${ }^{189}$ In that case, Intech, a registered investment adviser, engaged the third-party proxy voting service ISS to vote proxies in accordance with AFL-CIO proxy voting recommendations. ${ }^{190}$ Intech followed the AFL-CIO recommendations because it was participating in the annual AFL-CIO Key Votes Survey that ranked investment advisers based on their adherence to the AFL-CIO recommendations. ${ }^{191}$ Intech hoped that improving its ranking in the AFL-CIO Key Votes Survey would help it maintain existing union clients and recruit new union clients. ${ }^{192}$ Intech failed to note in its disclosures the material conflict of interest between itself and its clients who were not pro-AFL-CIO. ${ }^{193}$ Indeed, in its proxy voting policies, Intech noted that, because it relied on ISS, it did not "expect] that any conflicts w[ould] arise in the proxy voting process." 194 The SEC found, however, that Intech's actions violated the firm's duties to its investors. ${ }^{195}$

Common agency theory anticipates that the shareholder will act to maximize its own welfare, even if it does so at the expense of other shareholders. Indeed, fund beneficiaries may not only permit such self-serving actions, but encourage them. The fiduciary duties

186. Id.

187. Id. at * 4 .

188. Id.

189. In the Matter of Intech Investment Management LLC and David E. Hurley Respondents, Investment Advisors Act of 1940 Release No. IA-2872, 95 SEC Docket 2265, 2009 WL 1271173 (May 7, 2009).

190. Id. at *2.

191. Id. at $* 1$.

192. Id.

193. Id. at $* 2$.

194. Id. at * 4 .

195. Id. at ${ }^{\star} 6$. 
that the Department of Labor and SEC rules impose are owed to the beneficiaries of the investment fund, and not to the company or its other shareholders. Thus, we could imagine a transaction in which the adviser of a fund that owns four percent of the outstanding common stock of Company $A$, decided to pressure Company $A$ to enter into an agreement whereby Company $B$, in which the fund is a major investor, would be the exclusive supplier of a component of Company $A$ 's primary product. Suppose that Company $A$ will likely suffer a minor net loss as a result of the transaction, but that Company $B$ will enjoy a significant gain, such that the advisers will achieve a net gain on the transaction. There is nothing in either the SEC rules or the Department of Labor rules that would prohibit the advisers from engaging in such a transaction. They owe no fiduciary duty to the company, nor do they owe any fiduciary duty to any of the other shareholders. Further, even state corporate law would arguably not inhibit such selfish use of the shareholder's influence at the company, although the directors may be foolish to approve such a transaction.

In addition to ignoring these competing shareholder interests, federal application of fiduciary duties suffers from other limitations. First, the application of fiduciary duties to certain investment vehicles, and mutual funds particularly, is an imperfect fit. As Donald Langevoort has argued, a belief by fund fiduciaries in a conception of consumer sovereignty may reduce their willingness to more actively protect fund investors. ${ }^{196}$ Second, even if the fiduciaries sought to meet their responsibilities more vigorously (assuming at present they do not perform adequately), fiduciaries will find a relative lack of content with respect to the federal law of fiduciary duties. Although there are a number of cases discussing fiduciary duties with respect to management fees, ${ }^{197}$ the application of federal duties to other aspects of the fiduciary relationship is still relatively recent, and there is very little guidance from either the courts or regulators on how fiduciaries should behave. This problem will likely resolve itself over time because the institutionalization of U.S. securities markets suggests increased federal regulation of institutional investors and public corporations, with increased guidance from the SEC. Indeed, the expansion of shareholder influence will almost certainly diminish the importance of state law. The latest efforts by federal regulators will

196. Donald C. Langevoort, Private Litigation to Enforce Fiduciary Duties in Mutual Funds: Derivative Suits, Disinterested Directors and the Ideology of Investor Sovereignty, 83 WASH. U. L.R. 1017, 1017-44 (2005).

197. These cases culminate in Jones v. Harris Associates L.P., 130 S. Ct. 1418 (2010), recently decided by the Supreme Court. 
place significant pressure on states, particularly Delaware, to respond-not merely to provide relief from high common agency costs-but simply to remain relevant. The following Section reviews a proposal for a dramatic response from state regulators.

\section{Shareholder Fiduciary Duties to the Corporation and Other Shareholders}

A fiduciary duty owed by shareholders to the corporation would be a very direct regulation of common agency costs. Effectively, it would force shareholders to act as collective principals. Several scholars have argued that fiduciary duties should, at least in some cases, run from activist shareholders to the portfolio company. Unlike the fiduciary duties imposed on fund managers, these duties would presumably arise under state rather than federal regulation.

Focusing on the issue of shareholder nominations to the board of directors, Roberta Karmel argued that if institutions win the right to make nominations, as recently proposed by the SEC, the institutions should be held to the same duty imposed on controlling shareholders. ${ }^{198}$ Such an institution should monitor the appointed directors and remain a shareholder for the duration of the terms of office of such directors. Karmel also argued that the institutions should be prevented from using any power to nominate directors in conflict of interest situations, noting a particular danger of conflicts in the case of labor funds nominees "because they may be more interested in labor issues than shareholder issues." 199

Iman Anabtawi and Lynn Stout have also developed a thorough proposal for the application of fiduciary duties to activist shareholders. ${ }^{200}$ Anabtawi and Stout note that while minority shareholders are increasingly influential, the legal framework continues to assume that shareholders are rationally passive because of legal and economic barriers to shareholder activism. ${ }^{201}$ More importantly, the law assumes that minority shareholder activism is beneficial because even when shareholders do try to take an active role in public corporations, they are primarily concerned with improving the firm's overall economic performance in alignment with

198. Roberta S. Karmel, Should a Duty to the Corporation Be Imposed on Institutional Shareholders?, 60 BUS. LAW. 1, 20 (2004).

199. Id. at 21.

200. Anabtawi \& Stout, Fiduciary Duties for Activist Shareholders, supra note 144, at 1294.

201. Id. at 1283 . 
the interests of the firm and other shareholders. ${ }^{202}$ They note, however, that

\begin{abstract}
even as shareholders are becoming more powerful, their interests are becoming more heterogeneous. Increasingly, the economic interests of one shareholder or shareholder group conflict with the economic interests of others. The result is that activist shareholders are using their growing influence not to improve overall firm performance, as has generally been assumed, but to profit at other shareholders' expense. ${ }^{203}$
\end{abstract}

Anabtawi and Stout described several recent examples that demonstrate minority shareholders' willingness to use their shares to extract gains not shared by other shareholders. These examples include a labor union's pension fund threatening a proxy fight in order to obtain concessions for the union in a contract negotiation with the company, and a hedge fund threatening one of its portfolio companies with a proxy fight if the company did not purchase a target in which the hedge fund had a significant interest. 204

To protect against such opportunism, Anabtawi and Stout argued that fiduciary duties to the corporation should be imposed on minority shareholders in certain circumstances. ${ }^{205}$ These fiduciary duties would not be triggered by a particular shareholder's ability to direct corporate decisionmaking in the abstract, but rather by a shareholder's ability to influence the outcome of a particular corporate decision in which it has a personal conflict of interest. ${ }^{206}$ Anabtawi and Stout's formulation modernizes the idea of control "to account for the reality that modern shareholders can influence corporate policy through a variety of strategies that do not require them to control a numerical majority of the firm's voting shares."207 Under their proposal, a shareholder "controls" corporate conduct whenever its action determinatively causes a particular corporate decision. ${ }^{208}$

There are a number of concerns with subjecting minority shareholders to a fiduciary duty to other shareholders that Anabtawi and Stout addressed in their article. ${ }^{209} \mathrm{~A}$ primary concern is that attributing fiduciary duties to minority shareholders will encourage litigation. Anabtawi and Stout responded that the costs of litigation against self-dealing directors and controlling shareholders are outweighed by the benefits of such litigation to the corporation and

202. Id. at 1258 .

203. Id.

204. Id. at 1259.

205. Id. at 1288-1307.

206. Id. at 1299.

207. Id. at 1295.

208. Id.

209. Id. at 1303-07. 
other minority shareholders. ${ }^{210}$ Anabtawi and Stout also noted that the same substantive and procedural protections that discourage frivolous lawsuits alleging duty of loyalty violations by officers, directors, and controlling shareholders would be applicable in the case of activist minority shareholders. ${ }^{211}$

Another concern is that management could strategically use lawsuits to discourage activism. While Anabtawi and Stout rightly noted that litigation against conflict-free activists would not be successful, a suit or the threat of litigation could likely still be used strategically to dissuade even legitimate activism. ${ }^{212}$ Lawmakers could resolve this concern by restricting the right to bring an action to shareholders; managers could be allowed to bring an action only in their capacity as shareholders and would not have the resources of the corporation funding the litigation. On the other hand, such a restriction would dramatically limit the number of suits, reducing the effectiveness of their disciplining effect to enforce fiduciary duties of minority shareholders. ${ }^{213}$

If litigation concerns are not mitigated, Andrew Shapiro, a well-known activist investor, argued that the implementation of Anabtawi and Stout's proposal would create an incremental risk to shareholders that will raise the cost of all equity capital. ${ }^{214}$ In effect, shareholders will reduce the price paid for stock in order to compensate for the increased direct liability risk or the cost of purchasing insurance to hedge against such a risk. ${ }^{215}$

Shapiro also noted that a majority vote protects against many instances of shareholder activism, and even where it doesn't-for instance, where a shareholder vote is not required-"the buck stops

210. Id. at 1303-04. Yet there are constraints operating on directors that may not dissuade hedge funds, such as the reputational effects of engaging in self-dealing transactions. However, one could also assume that such activities have a reputational effect on the hedge funds, although not for the same reason. The effect on directors would be that the director's desirability as a public company director would be diminished, which could affect re-election and nomination to other boards. For hedge funds, the reputational effect could be heightened scrutiny by other companies in which the hedge fund chooses to invest. In both cases, the ability to engage in selfdealing transactions may be diminished.

211. Id. at 1303 .

212. Andrew Shapiro, Comment to Lynn A. Stout, Fiduciary Duties to Activist Shareholders, HaRv. L. Sch. CoRP. Governance \& Fin. Regulation Blog (Mar. 3, 2008, 17:26), http://blogs.law.harvard.edu/corpgov/2008/03/03/fiduciary-duties-for-activist-shareholders/.

213. If such suits were brought on a contingency basis, for example, the amount of damages at issue in the suit-corresponding to the private benefit extracted by the minority shareholders-would have to be quite large to induce an attorney to bring the suit. I thank Roberta Romano for these insights.

214. Shapiro, supra note 212.

215. Id. 
with the Board (and 'control' shareholders) where fiduciary duty properly should rest."216 However, activist minority shareholders are increasingly engaging in undisclosed, nonpublic negotiations with management, preventing shareholders from being able to evaluate or manage the agency costs created by such activity. A perverse result may emerge: activists that engage in benefit seeking may decide to share gains from such benefits with management. Management may engage in such benefit sharing even if activist investors owe fiduciary duties both because of the costs involved in defending against activism and the rewards that may be offered by activists - continued proxy support being the least offensive possibility. Activists, so long as they are willing to share benefits, will be able to extract value from the corporation despite conflicts. The primary guardians against such activity, directors and officers, may be incentivized to refrain from suing the activists.

Finally, imposing fiduciary obligations on minority shareholders could be a significant risk for states that are competing for incorporations and reincorporations, even if fiduciary duties would have the beneficial effect of reducing some shareholder-generated common agency costs. The shareholders of all companies, regardless of the state of incorporation, have increased influence largely through federal proxy rules. However, state law still regulates the basic governance structures of corporations, and fiduciary duties, in particular, provide a means of calibrating director and manager behavior. When the Delaware Supreme Court recalibrated the effect of fiduciary duties in Smith $v$. Van Gorkom, ${ }^{217}$ the legislature thought the potential for loss of incorporations so great that it quickly responded to the effects of the decision with a liability exculpation statute, Section 102(b)(7) of the Delaware General Corporation Law. ${ }^{218}$ Assuming Shapiro's concerns over litigation are valid and given that shareholders are more active generally (in that even traditionally passive investors are increasingly willing to vote for corporate governance and social proposals), activist shareholders would be disinclined to approve a reincorporation of a regime that chilled activism. Moreover, proxy advisory firms, who often provide support for activist investors, would influence other shareholders by recommending against reincorporation.

216. Id.

217. 488 A.2d 858, 872-873 (Del. 1985).

218. DEL. CODE ANN. tit. $8, \S 102(b)(7)(2010)$. 


\section{Duties Owed by Managers to Shareholders}

As an alternative to applying fiduciary duties to activist minority shareholders, an understanding of the effects of common agency could encourage states to protect the value of their corporate law by more actively applying the traditional notions of fiduciary duty that managers and directors owe to the company's shareholders. The recent case of Portnoy $v$. Cryo-Cell International, Inc. ${ }^{219}$ provides an example. In Portnoy, Vice-Chancellor Leo Strine reviewed a proxy contest in which the management agreed with an activist shareholder, Andrew Filipowski, to allow the investor a seat on the board of directors in exchange for Filipowski's vote for the remainder of the management slate. ${ }^{220}$ However, management did not disclose that the board planned to add another seat to the board of directors after the election in order to seat another Filipowski designee. ${ }^{221}$ The designee, a Filipowski subordinate, had recently settled an insider trading charge with the SEC. ${ }^{222}$ Thus, shareholders would effectively have been voting on two seats for Filipowski, one of whom was "a person whose recent past would have weighed heavily on the mind of a rational stockholder considering whether to seat him as a fiduciary." 223

Vice-Chancellor Strine found that the voting arrangement between management and Filipowski was a material agreement that should have been disclosed. ${ }^{224}$ When viewing the first part of the deal between management and Filipowski-the election of Filipowski to the board in exchange for his votes for the rest of the management slate-Strine declined to impose an entire fairness review as with a pure vote-buying arrangement. ${ }^{225}$ However, he noted in dicta "that there is not a hint that Filipowski sought to receive financial payments from Cryo-Cell in the form of contracts or consulting fees or other such arrangements." 226 A settlement in which consulting fees or other financial benefits are conferred on a shareholder in exchange for votes would clearly fall under the entire fairness standard required

219. 940 A.2d 43, 46 (Del. Ch. 2008).

220. Id.

221. Id. at $46-47$.

222. Id. at 46.

223. Id. at 72 .

224. Id. at 72 (" $[\mathrm{D}]$ irectors of Delaware corporations are under a fiduciary duty to disclose fully and fairly all material information within the board's control when it seeks shareholder action .... [Such] obligation attaches to proxy statements and any other disclosures in contemplation of stockholder action.") (citations omitted).

225. Id. at 68 .

226. Id. at 70 . 
under Schreiber. ${ }^{227}$ Indeed, Schreiber holds that even where an agreement between management and a shareholder is in the best interests of all the company's stockholders, the agreement merely is voidable, rather than per se void. ${ }^{228}$ Only "the subsequent ratification of the transaction by a majority of the independent stockholders, after a full disclosure of all germane facts with complete candor," 229 removes the taint on the transaction. Except for voting agreements that result in board seats, however, it seems that other agreements between shareholders and management are not disclosed, although Schreiber can be read as suggesting that they should be-an ambiguity that Delaware courts should address if given the opportunity. Although there may not be an actionable breach of fiduciary duty if, for example, management agrees to adopt a suboptimal governance structure after negotiations with a shareholder-the business judgment rule would offer significant protection for management, provided there are no conflicts of interest-business judgment review of the agreement could be conditioned on disclosure of the agreement.

Portnoy underlines the connection of disclosure-the focus of the following Section-to the enforcement of fiduciary duties. If, for example, states were to impose fiduciary duties on minority shareholders, the application of enhanced disclosure obligations would serve to facilitate the enforcement of fiduciary duties, just as it facilitates enforcement of fiduciary duties against directors, managers, and controlling shareholders.

\section{B. Regulation by Disclosure}

Disclosure of shareholder activism, as with disclosure of management dealings, may also reduce costs associated with common agency. Well-crafted disclosure obligations could discourage the pursuit of private benefits, reveal at least some lobbying costs, and promote the selection of governance choices that relate to long-term performance. The limited disclosure requirements proposed here reflect a precautionary principle by shining light on investor activity but not significantly altering the current balance of corporate power. We do not yet have a complete picture of how shareholders use their enhanced power and influence, although the research discussed above provides evidence that some shareholders will use this power in ways that harm other shareholders and corporate constituents. The

227. Schreiber v. Carney, 447 A.2d 17, 26 (Del. Ch. 1982).

228. Id. at 26 .

229. Id. 
disclosures proposed in this Section discourage detrimental forms of shareholder influence and improve the effectiveness of existing fiduciary standards. The goal of the disclosures is to encourage collective shareholder action and to reduce the opportunity for common agencies to develop.

Federal disclosure requirements, operating consistently with a shareholder primacy model, have been used to provide effective monitoring of management shirking or benefit seeking. For instance, a public corporation is required to disclose executive compensation, as well as transactions between the company and management, directors, or other related parties. ${ }^{230}$ Aside from disclosures that may already be made in response to state corporate laws (e.g., disclosure of self-dealing transactions), federal securities laws also provide some disclosure-based regulation of shareholder influence. Some basic disclosures are required of significant shareholders under the framework set out in Section 13(d) of the Exchange Act ${ }^{231}$ and Schedule 13D promulgated thereunder, ${ }^{232}$ which was originally created to limit coercive tender offers. Currently, detailed disclosures under Schedule 13D are required only when the minority shareholder owns more than five percent of the outstanding stock of the company and the investor is not eligible for the less descriptive disclosures required of "passive" investors owning between five and twenty percent of the company's outstanding stock. ${ }^{233}$ Where an investor must file under Schedule 13D, the investor is required to disclose the purpose of the acquisition of securities. ${ }^{234}$ The SEC is particularly concerned with purposes that demonstrate nonpassivity, including: causing the corporation to engage in an extraordinary corporate transaction, such as a merger, reorganization, or liquidation; selling or transferring a material amount of assets; effecting a change in the present board of directors or management; materially changing the present capitalization or dividend policy of the corporation; changing the corporation's charter or bylaws; or engaging in actions that may impede the acquisition of control of the corporation by any person..$^{235}$

An implicit justification for the disclosures of Schedule 13D is to provide information on other shareholders as an agency-cost reducing mechanism in the event of a contest for control. Presumably,

230. 17 C.F.R. $\$ 229.404$ (2010).

231. 15 U.S.C. $\$ 78 \mathrm{~m}$ (d) (2010).

232. 17 C.F.R. $\$ 240.13 d-1$.

233. Id.

234. Id.

235. Id. 
for example, if a benefit-extracting raider had designs on a company and was required to disclose an interest in control under $13 \mathrm{D}$, other investors may be inclined to sell. As a result, some shareholder crossmonitoring is already possible and no doubt often occurs when an activist shareholder obtains five percent of a company's stock. However, many influential shareholders do not own five percent of a company's outstanding stock, or they may hide their economic interest (even if greater than five percent) through a variety of devices, including derivative transactions and structures. ${ }^{236}$

The SEC also imposes agency cost-reducing disclosure obligations through Item 404 of Regulation S-K, which serves to reduce agency costs arising from both management benefit seeking and activist minority shareholder benefit seeking. ${ }^{237}$ Under 404(a), the company must describe any transaction or any currently proposed transaction in which the company was or is to be a participant if the amount involved exceeds $\$ 120,000$, and if any "related person" had or will have a direct or indirect material interest. 238 The term "related person" encompasses, among others, officers, directors, and five percent blockholders. ${ }^{239}$

In some circumstances, shareholders holding less than five percent may exert enough influence over the corporation to cause the corporation either to adopt or propose via proxy statement ill-advised governance changes or to engage in transactions benefiting the activist to the detriment of other shareholders. As a result of the disclosure requirements under $13 \mathrm{D}$, shareholders are encouraged to remain under the five percent threshold. Schedule 13D will not limit agency costs attributable to shareholders that own less than five percent of the company's outstanding stock, even if the shareholder holds economic interests in greater than five percent of a company's shares through, for example, a derivative structure such as a total return swap. Even activist investors that should disclose their activities under 13D do not always comply with the filing requirements. ${ }^{240}$ Further, because $13 \mathrm{D}$ is focused on transactions that evidence control rather than influence, Schedule 13D does not require

236. 17 C.F.R. $\S 229.404$.

237. Id.

238. $I d$.

239. $I d$.

240. Steven Davidoff notes, however, that some shareholders are failing to file 13D statements despite their intention to engage in activism. See Steven Davidoff, Season of Their Discontent, N.Y. TIMES DEALBOOK BLOG, (Mar. 13, 2008, 10:59 AM), http://dealbook.blogs.nytimes.com/2008/03/13/season-of-their-discontent/. 
disclosure of many corporate decisions resulting from shareholder influence.

The securities laws begin with the assumption that regulation of shareholder influence should generally be tied to the size of a company's holdings. However, the agency costs that activist investors create are not directly limited by the size of the activist's block of shares. The SEC's model thus limits the scope of regulated shareholder influence to holders of greater than five percent, but not necessarily those whose activities have the largest effect on a particular company's governance or policies. Indeed, many firms may not have any activist five percent holders, yet may still be subject to significant shareholder influence by blockholders owning less than five percent of the firm's equity. Rather than trying to force $13 \mathrm{D}$ beyond its intended use, the SEC could regulate shareholder influence using a disclosure trigger that is not tied to a numerical threshold. One possibility is to adopt a rule analogous to a provision that the Treasury Department employs in its regulation of acquisitions by foreign shareholders-where risk is not dictated solely by how much a shareholder owns (although risks may increase as the shareholding size increases), but rather by what the shareholder does. ${ }^{241}$ Thus, the SEC could require shareholders to disclose their activities whenever they cause a corporation to act in ways that increase agency costs. Practically, the granting of special benefits to the activist shareholder, perhaps in exchange for some concession from the shareholder, would trigger this disclosure requirement.

In their proposal to impose fiduciary duties on activist investors, Anabtawi and Stout hinged the imposition of a duty on whether the activism was a determinative "but for" cause of any corporate decision. ${ }^{242}$ Likewise, disclosure obligations could also be imposed where the shareholder's activism was the determinative cause of a corporate decision. However, we could differentiate here between two forms of potential regulation, which would have differing effects on a common agency relationship. In the first, narrower form of disclosure regulation, we could limit the application of disclosure

241. 31 C.F.R. pt. 800.204 (2010). The Treasury regulates influential minority investors by clarifying the difference between mere influence and "control," and attaches scrutiny to transactions or events that demonstrate control. The Treasury regulations are not designed to regulate agency costs per se, but more narrowly regulate national security issues that may arise from foreign control of U.S entities. However, the analogy is apt in the sense that the regulations attempt to constrain activity of investors that have interests that diverge from the company and other investors. Sovereign wealth funds, particularly, are seen as the archetypal investor having interests that may diverge significantly from those of other shareholders.

242. Anabtawi \& Stout, Fiduciary Duties for Activist Shareholders, supra note 144, at 1295. 
requirements to circumstances in which the shareholder activism is the proximate cause of a corporate decision and the decision provides a special benefit to the shareholder causing the decision. In a second, broader form of disclosure regulation, we would apply disclosure requirements simply where the shareholder was the proximate cause of the decision, without regard to whether the shareholder receives any personal benefit from the transaction. In each case, the disclosure is designed to shine light on dealings between shareholders, directors, and management resulting in agency costs for other shareholders. The disclosure requirement would run not only to situations involving transactions, but also to shareholder influence over governance matters. Shareholders proposing beneficial governance changes through private negotiations or through the proxy process should not be adversely affected, since disclosure will not reveal any private benefits.

The SEC has designed many of its disclosures to specifically address agency cost-producing activities of management. The extensive disclosures relating to executive compensation, for instance, are prominent examples of this focus. As noted above, disclosures of other sources of agency costs, including related-party transactions, are made annually pursuant to Item 404 of Regulation S-K. Item 404(a) would be a logical place to require basic disclosure of direct agency costs (where the shareholder obtains a private benefit), since Item 404(a) disclosure already requires disclosure of certain transactions between the company and shareholders. However, Item 404(a), like $13 \mathrm{D}$, does not require disclosures unless the shareholder owns more than five percent. Because agency costs are not necessarily related to ownership percentage, amending Item 404(a) to require disclosure whenever, as a result of a transaction or by agreement with the company, a shareholder obtains a material benefit that is not shared pro rata with the rest of the shareholders could resolve the common agency costs that shareholder activism creates. As with current Item 404(a), the SEC could exempt de minimus transactions involving less than $\$ 120,000.243$

The broader form of disclosure requirement could require disclosure of any material event of which a shareholder of the company is a proximate cause, but would be more difficult to place within existing securities disclosures. Primarily, the disclosure would involve a brief summary of negotiations between the company and the shareholder, as well as the result of such negotiations. As described above, a typical method of exerting influence on companies is through 
the proxy process. Shareholders will put forward a proposal in order to encourage management to negotiate. If management chooses to negotiate, the shareholders may withdraw their proposal if the company agrees to certain conditions, such as changes in the corporate governance structure. Management may also make a proposal that is a modified version of the shareholder proposal. In either case, typically no disclosure is made of the negotiations between management and shareholders that led to the particular outcome. Because this kind of influence is usually, although not exclusively, associated with the annual proxy process, Schedule 14A seems an appropriate place to house such disclosure requirements.

Note that the disclosure obligations considered here would be made by the company, not the shareholder. By requiring the company to make the disclosure, the regulation of common agency costs through the application of fiduciary duties becomes more effective. Enhanced federal disclosure requirements would also leverage state and federal fiduciary obligations. As noted above, the provision of benefits to particular shareholders is not merely an agency cost imposed by the shareholders, but is often accompanied by increased agency costs imposed by management (for instance, when an activist agrees to support wasteful management proposals or when an activist agrees not to wage a proxy campaign to remove a poorly performing board). Disclosure of such influence would make it easier to police such activities, and because such undisclosed side-deals implicate the duty of loyalty, management would not automatically receive the protection of the business judgment rule. ${ }^{244}$

The enhanced disclosure obligations described in this Section are a minimalist response to the problem of common agency in public corporations, and are a realistic extension of existing regulations. As with the imposition of enhanced fiduciary duties, however, there are significant complications with the expansion of disclosure obligations. First, a requirement to disclose transactions in which a shareholder has a material interest may be overly broad and would require the disclosure of what might be called "unintentional" conflicts of interest. An agreement with a shareholder to manage a pension plan, for example, would be disclosed. However, Item 404, as currently in effect, makes provision for similar concerns by excepting transactions

244. Note also that enhanced disclosures could help CFIUS, which regulates foreign investment, function more effectively. Because CFIUS only applies in control transactions, the ability of regulators to be made aware of activities falling under the definition of control is vital to the functioning of the CFIUS regulations. The disclosure requirements suggested here would help insure that regulators are apprised of transactions suggesting control. 
involving competitive bids or where fiduciary obligations serve a moderating effect, as in transactions involving "services as a bank depositary of funds, transfer agent, registrar, trustee under a trust indenture, or similar services." 245

A second complication is that additional disclosures may be redundant; certain agreements between shareholders and companies may also effectively require disclosure under some state laws, as in the Portnoy case. SEC rules, particularly Item 601 of Regulation S-K, also require disclosure of material contracts and voting trust agreements. ${ }^{246}$ Some deals, such as relational investor deals whereby an investor receives discounted preferred stock, will require disclosure because they are material. Generally, though, many agency costproducing transactions or agreements are not disclosed. There are at least four reasons why this disclosure does not occur. First, in the case of disclosures such as those required by Portnoy, state corporate law typically does not explicitly require disclosure. The law simply enhances scrutiny and the burden on the defendants if the transaction is not disclosed. Second, some agreements may be deemed immaterial to investors. This is not likely to be the case with agreements in which another shareholder has a material conflict of interest and is receiving benefits that are not shared pro rata, however. Third, many of the agreements made between shareholders and management or the board may not always take the form of a written record, and so there is no formal contract such as would be disclosed under Item 601 . Finally, many agreements may be material to investors, and should therefore be disclosed, but are not because there is little incentive for management to disclose an agreement that is not explicitly required to be disclosed, especially if the agreement exposes agency costs that may be actionable as a breach of fiduciary duty. There is likewise little incentive to disclose if there is no regulatory cost or sanction for failure to disclose.

More significantly, however, disclosure may be redundant simply because some activist shareholders (such as Bill Ackman) already use disclosure as a means to enhance their influence. This redundancy may not be harmful since such public activism is more likely to be value-enhancing and beneficial to all shareholders. Disclosure may have the effect of encouraging more influenceindependent directors, wary of being voted out, will want to show engagement. But influence is not necessarily a bad thing if we believe that the reduction of agency costs will offset any common agency 
inefficiencies. Disclosure simply helps to ensure that we can account for private benefits and other costs of shareholder influence. As a result, directors should be less likely to provide any special benefits to influential shareholders. ${ }^{247}$ The goal for enhanced disclosure requirements would thus not be to limit agency cost-reducing shareholder activism, but simply to add more accountability in common agency relationships.

Another possible complication is that disclosure of agreements between shareholders and companies would chill communications between companies and investors and would serve to reduce agency cost-reducing activism. Under the weaker form of the disclosure requirements, we would almost certainly not see a reduction in many "good governance" initiatives, however, since such measures (even if of dubious value) will affect all shareholders on a pro rata basis and would thus not be required to be disclosed. If such good governance mechanisms are not positively related to firm performance, we should see a decline in their use if data eventually reveal their lack of value. We likely would see a decline in some forms of hedge fund activism, however, if such activism is premised on the basis of non-pro rata gains to be extracted by the hedge fund. In most cases, this result should not harm passive shareholders. Passive shareholders stand to see losses from high management costs, and in some cases, activists may merely agree to split these costs with management. ${ }^{248}$

Although the proposals suggested here are not designed to discourage beneficial, agency cost-reducing, shareholder influence, if

247. On a similar point, Macey and McChesney argue that "[p]aying greenmail is doomed to fail as other greenmailers will come along and demand similar payments. Unless rather restrictive assumptions are made about the greenmail process, management teams paying greenmail to protect their jobs are at best myopic, and perhaps irrational." Jonathan R. Macey \& Fred S. McChesney, A Theoretical Analysis of Corporate Greenmail, 95 YALE L.J. 13, 41-42 (1985). Choi and Talley make a related argument:

[A]llowing patronage from managers to block shareholders that work to entrench management may, on first blush, seem to reduce overall corporate welfare. From an ex ante perspective, however, the possibility that outside investors may assemble blocks of shares simply to extract a bribe from management may have underappreciated positive welfare implications: In particular, it creates an added incentive for management to work hard so as to avoid being held up by opportunistic block shareholders. Viewed in this sense, two wrongs can indeed make a right. Opportunism on the part of outside investors seeking a bribe can dampen the effect of managerial agency costs, causing managers to commit to a lower level of private benefits to deter the outside investors from forming a block in the first place.

Steven Choi \& Eric Talley, Playing Favorites with Shareholders, 75 S. CAL. L. REV. 271, 343-44 (2002). Notably, the reduction of agency costs under Choi and Talley's model is enhanced by "disclosure of existing relationships between managers and pre-existing block shareholders." Id. at 359 .

248. However, passive investors may be marginally harmed by such disclosure if activists have routinely split some of these costs with passive shareholders. 
the disclosure proposals were enacted, particularly in their strong form, there may be a reduction in "good governance" proposals. Certain activist shareholders would not prefer the disclosure requirements suggested here because their negotiations would increase scrutiny of their activities with companies. This additional examination could result in other investors attempting to replicate such methods, or in the case of regulated investors, such as certain pension funds, could invite scrutiny into whether the investor complied with fiduciary standards. For example, while pursuing a corporate governance-related proposal may be innocuous, the pursuit of a corporate governance proposal while the fund's related union is involved in union-related negotiations would likely draw the Department of Labor's attention. Such a scenario is unlikely to be common, however, and if shareholder activism is as beneficial as its proponents suggest, activists have little to fear from disclosure of their activities.

Implementing the disclosure requirements described here may present enforcement challenges. Because management-agents may be sharing private benefits with shareholders, managers are disincentivized from disclosing such benefits, for fear of encouraging a suit for breach of fiduciary duties. Note, however, that companies regularly face similar concerns with many related-party transactions, which typically must be disclosed. As with related-party transactions, encouraging disclosure would require an SEC commitment to a robust internal controls framework, buttressed by at least periodic attention from the SEC's Division of Enforcement.

Finally, this Article has argued for mandatory disclosures rather than soft law solutions such as voluntary "best practices" disclosures of the results of shareholder activism (such as could be developed by an organization such as the Council of Institutional Investors ${ }^{249}$ ), primarily because best-practices disclosures would

249. The Council of Institutional Investors has adopted the following brief statement on "Best Disclosure Practices for Institutional Investors":

In order to foster an environment of transparency and accountability, institutional investors-including pension funds, hedge funds, private equity firms and sovereign wealth funds, among others-should make publicly available in a timely manner:

Proxy voting guidelines;

Proxy votes cast;

Investment guidelines;

Names of governing-body members; and

An annual report on holdings and performance.

COUNCIL OF INST. INVESTORS, STATEMENT ON BEST DISClosure PRACTICES For INSTITUTIONAL INVESTORS 1 (2009), available at http:/www.cii.org/UserFiles/file/Statement\%20on \%20Best\%20Disclosure\%20Practices\%20for\%20Institutional\%20Investors.pdf. 
obviously be less enforceable than mandatory disclosures. An intermediate position between voluntary disclosures and the mandatory disclosures described in this Article is the "comply-orexplain" approach currently under consideration by the UK's Financial Reporting Council (FRC). The FRC's proposed "Stewardship Code" would seem to require disclosure of only the policies behind the shareholders' activism inputs, and not disclosure of the corporate outputs resulting from the activism. ${ }^{250}$ It is possible but unlikely that an industry organization would develop such a code of best practices for activism disclosure, and even less likely that shareholders seeking private benefits would voluntarily provide disclosures of their activities. Alternatively, the SEC could enact comply-or-explain regulations that would apply to shareholders, rather than as part of the corporation's disclosures. Such disclosures would seem to fit under Schedule 13D, although as discussed above, Schedule 13D is designed to regulate the market for corporate control rather than shareholder activism.

\section{CONCLUSION}

This Article analyzes recent increases in shareholder power in public corporations and proposes a common agency theory to describe and analyze management-shareholder relations in public corporations. Under this theory, shareholder influence is not merely a means of limiting managerial expropriation, but also may be a source of agency costs. Therefore, increasing shareholder influence may have both positive and negative effects. Used appropriately, shareholder activism could, for example, play an important role in reducing management agency costs by increasing director responsiveness to shareholder concerns over board and management entrenchment. ${ }^{251}$ On the other hand, shareholder influence may also increase agency costs due to the necessity of shareholder cross-monitoring and because increasing shareholder power and influence may lead to increased private benefits for particular shareholders. Academic and regulatory efforts to promote shareholder influence of public corporations have largely ignored the agency costs associated with such influence and

250. See Fin. REPorting COUNCIL, CONSUltation on A StEWARdShIP CODE FOR INSTITUTIONAL INVESTORS (2010), available at http://www.frc.org.uk/images/uploaded/ documents/Stewardship\%20Code\%20Consultation\%20January\%202010.pdf (discussing development of a Stewardship Code).

251. See, e.g., Randall S. Thomas \& James F. Cotter, Shareholder Proposals in the New Millennium: Shareholder Support, Board Response, and Market Reaction, 13 J. CORP. FTN. 368 (2007) (discussing the role of shareholder activism in increasing director responsiveness). 
activism. Such costs must be weighed against the purported gains from shareholder influence.

Enhanced fiduciary obligations at the state and federal levels could help to limit the costs of common agency. Additional disclosures, either in conjunction with expanded fiduciary duties or merely as reinforcement for existing duties, could also help ensure that shareholder influence decreases, rather than increases, total firm agency costs. Disclosure of the results of shareholder influence would allow for cross-monitoring by other shareholders, thereby allowing shareholders to better manage risks of noneconomic influence on corporate activities. This should be a crucial means of monitoring the behavior of activist institutions and should reduce the likelihood of noneconomic activism by, for example, public pension funds, sovereign wealth funds, or other government-controlled entities. We should not expect to see significant economic costs to this disclosure, because the company would not be required to gather any information that it does not already possess-it would simply need to report on any changes that were made as a result of negotiations between the company and any shareholder. This disclosure would also serve as a means to monitor managers, since it provides insight into what they are agreeing to and why.

In common agency situations, such as with representative governments, there are checks and balances to protect against control by factions. ${ }^{252}$ With shareholders, as with the factions discussed in Federalist No. $10,{ }^{253}$ we may conclude that the causes of heterogeneous, influential groups are probably not capable of being removed; as argued in this Article, the cause of increasing power for shareholders is an increasingly expansive federal law of the public corporation. It may be possible, however, to control some of the effects of shareholder factions through disclosure.

If unmonitored, the increase in shareholder influence has the potential to significantly diminish the value of the corporate form. Although the notion of shareholder empowerment is often presented as a kind of democratic uprising against imperial CEOs and crony

252. On this point, Dixit remarks:

We have multi-principal politics for a reason, namely, to provide checks and balances against biased or arbitrary exercise of power. This was emphasized in the Federalist papers, especially Numbers 10 and 51 . . But one should recognize that this benefit comes with an attendant cost, namely, weak incentives, which can lead to indecision or gridlock. In politics, as in economics, the first-best is elusive, and we must accept many unsatisfactory compromises.

Dixit, supra note 29 , at 381 .

253. The FEDERALIST No. 10 (James Madison). 
boards of directors, a reactive reallocation of power in the name of corporation democracy may result in oligarchies in which managers and influential shareholders share power and occasionally act at the expense of passive shareholders and other corporate constituencies. The SEC should act to manage the costs of common agency if it hopes to maintain the utility the corporate form as an investment vehicle, rather than as a financial oligarchy that rewards its most powerful constituents at the expense of less influential constituents. If public corporations experience higher agency costs because of common agency, some investors will not wait for a regulatory response. Indeed, many investors with a choice have reallocated funds to what Larry Ribstein calls "uncorporations" 254 : investment vehicles and operating firms structured as LLCs, partnerships, and other noncorporate forms. If the SEC weighs only the benefits of shareholder power but ignores the costs, common agency costs will continue to increase, and we should expect to see an increasing shift away from the corporate form and/or a determination by private firms to avoid public company status. 
